\title{
The Real Effects of Financial (Dis)integration:
}

\section{A Multi-Country Equilibrium Analysis of Europe}

\author{
Indraneel Chakraborty ${ }^{1} \quad$ Rong Hai $^{2} \quad$ Hans A. Holter ${ }^{3} \quad$ Serhiy Stepanchuk $^{4}$
}

October 24, 2016

\section{Prepared for the Carnegie-Rochester-NYU Conference Series on Public Policy, April 2016}

\begin{abstract}
Using data from 15 European Union economies, we quantify the real effects of supply-side frictions due to the financial disintegration of European countries since the 2008 financial crisis. We develop a multi-country general equilibrium model with heterogeneous countries and destinationspecific financial frictions. Financial institutions allocate capital endogenously across countries, determining the cost of capital to firms and the wealth of nations. The cost of financial disintegration is reduced access to capital for firms which results in lower output. Financial disintegration leads to a $0.54 \%$ fall in output in Europe since the crisis. We also estimate benefits of further financial integration.
\end{abstract}

Keywords: Financial Integration, Global Financial Crisis, Europe, Financial Institutions, Crossborder Financing.

JEL: E44, E58, F36, F45, F62, G15, G21.

We thank Mark Aguiar, George Alessandria (Editor), Mark Bils, Raphael Boleslavsky, Vidhi Chhaochharia, Harold Cole, Stefania Garetto (Discussant), Linda Goldberg, Itay Goldstein, Marvin Goodfriend, Urban Jermann, Narayana Kocherlakota, George Korniotis, Alok Kumar, Leonid Kogan, Salvador Ortigueira, Fabrizio Perri, Tarun Ramadorai, Dennis Reinhardt, Linda Tesar (Editor), Harald Uhlig, and participants at the Carnegie-Rochester-NYU Conference on Public Policy and University of Oslo for helpful comments and suggestions. Sarah Khalaf provided excellent research assistance.

${ }^{1}$ University of Miami, i.chakraborty@miami.edu. Corresponding author, contact information: i.chakraborty@miami.edu, Phone: (312) 208-1283, Postal Address: University of Miami School of Business Administration, 5250 University Drive, 512-A Jenkins Bldg., Coral Gables, FL 33124.

${ }^{2}$ University of Miami, rhai@bus.miami.edu

${ }^{3}$ University of Oslo, hans.holter@econ.uio.no

${ }^{4}$ University of Southampton, s.stepanchuk@soton.ac.uk 


\section{Introduction}

Global financial integration and in particular a more integrated Europe have been important policy goals, until the 2008 financial crisis. During the crisis, policymakers attempted to reduce financial contagion by "ringfencing" risks within national regulatory boundaries. While this helped limit financial contagion, it also created a segmentation of credit markets. After the financial crisis and the sovereign debt crisis, the general policy consensus has been that "financial interconnections can be too destabilizing" (European Commission, 2015). Recent academic literature has also addressed the costs of financial integration (See Bolton and Jeanne, 2011; Farhi and Tirole, 2014; Uhlig, 2014, among others). In sum, financial integration in Europe seems to have unraveled since the financial crisis and the sovereign debt crisis.

This paper seeks to quantify the costs of financial disintegration to the European economy. Such analysis allows a better understanding of the trade-off involved between systemic risk reduction and costs on the economy due to reduced bank lending. We focus on the change in barriers to capital flows in the European Union since the Great Recession. These international capital flows could be through equity or debt and could be done by financial institutions such as banks or mutual funds, or by individuals.

To infer the changes in the barriers to capital flows we develop a multi-country, general equilibrium model of international capital allocation among heterogeneous countries. In our model, heterogeneous countries solve an optimal portfolio diversification problem with the objective of maximizing risk-adjusted returns. We estimate destination-specific haircuts (financial frictions) that can justify the observed post-crisis capital flows by targeting moments on the share of foreign investments before and after the financial crisis. ${ }^{5}$ We find that the estimated GDP-weighted financial frictions in Continental Europe increased by $54.3 \%$ between the two time periods 2000-2007 and 2008-2011. We then quantify the impact of these changes on the level and distribution of economic activity and welfare. We find that the increase in financial disintegration leads to a $0.54 \%$ drop in GDP. The welfare loss is 0.20 percentage point in terms of consumption equivalence.

\footnotetext{
${ }^{5}$ Data on foreign claims outstanding are used for the identification.
} 
Trade in the EU has grown significantly for decades. However, the European economy is divided across political boundaries, with each nation deciding policies for its own benefit. The right panel of Figure 1(a) shows that business lending in the EU countries, as measured by the stock of loans reported, has not risen much after the crisis. The left panel of Figure 1(a) shows that gross incoming cross-border financing, as measured by the stock of loans as a fraction of output, has been falling steadily since the crisis. ${ }^{6}$ While a portion of the decline in cross-border financing may be attributable to an increase in sovereign risk and a decline in demand for capital in Europe, this paper seeks to understand what fraction of this difference is due to supply side factors; specifically financial disintegration. Figure 2 shows the fraction of incoming cross-border financing to total financing by domestic and cross-border financial institutions. ${ }^{7}$ The figure shows that incoming cross-border financing as a fraction of total financing (domestic and cross-border) has declined. ${ }^{8}$

Two concerns should be addressed before we move forward. First, did cross-border financing fall beyond a general decline in domestic financing? Second, to what extent is the fall explained by a fall in flows to countries with high sovereign risk, such as Greece? Figure 1(b) and Table 1 show the fraction of cross-border financing into a country as a fraction of total financing by domestic financial institutions (FIs) and cross-border FIs. ${ }^{9}$ The argument is that more financially integrated countries receive more cross-border financing, and thus a higher fraction suggests more integration. The left panel of Figure 1(b) shows a longer time period and the six largest European economies. The right panel focuses on three major economies in continental Europe and shows the decline in financial integration post-crisis in more detail. Germany, which is the largest capital provider to the rest of Europe, did not experience a significant drop in cross-border financing, but France

\footnotetext{
${ }^{6}$ Data from the U.S. are included for comparison. Data are obtained from Bank for International Settlements (BIS) Statistics Explorer Table C3 (See http://stats.bis.org/statx/srs/table/c3, details in Section 2). Data for the right panel are obtained from European Central Bank Statistical DataWarehouse (See https://sdw.ecb.europa.eu/browse.do?node=8549726) and the Federal Reserve Bank of St. Louis (FRED Economic Data, See https://fred.stlouisfed.org/series/BUSLOANS/).

${ }^{7}$ The fractions are calculated using the stock of gross claims outstanding against firms of a specific country in a year using data from BIS Statistics Explorer Table C3. Details of the calculation are in Section 2.

${ }^{8}$ Table 1 discussed later in Section 2 provides detailed information regarding cross-border financing.

${ }^{9}$ Data for this figure are also obtained from data from BIS Statistics Explorer Table C3.
} 
and Spain did. While one may argue that Spain faced sovereign risk and hence lost cross-border capital (BBB+ credit rating from S\&P), the right panel shows that the same is true even for France despite its very high credit quality (AA credit rating from $\mathrm{S} \& \mathrm{P}$ ). Thus, cross-border financing fell beyond a general decline in domestic financing, and this fall is not specific to countries with high sovereign risk.

The paper seeks to quantify the benefits of financial integration in the run-up to the crisis and the costs of the disintegration of credit markets since the crisis. The benefit of financial integration is measured in this paper by an increase in aggregate output and by conducting a welfare analysis in consumption equivalents. The cost of financial disintegration is also measured in the same manner.

In order to arrive at its conclusions, the paper develops a multi-country general equilibrium model with heterogeneous countries. Countries differ based on firm productivity, household capital, labor force characteristics, and destination-specific haircuts. In the model, financial institutions intermediate household capital flows within the country and across the border to the other 14 countries. The objective of the capital allocation decision is to maximize risk-adjusted returns through diversification of assets across the countries. The key friction in this international capital flow decision is financial, i.e. households from one country obtain a return on the capital invested in another country based on the level of financial integration between the two countries. As domestic rates of return on investment are endogenous outcomes per country based on the local demand, and across our $15 \mathrm{EU}$ country area, the supply of capital, the financial integration constraints create heterogeneous costs of capital for firms. The representative firm in each country maximizes profits using a Cobb-Douglas production function where the firm faces country-specific productivity, labor supply, the depreciation rate of capital, and output elasticity of capital. Capital and labor rental rates are determined in equilibrium based on cross-country capital allocation decisions of households in the 15 countries discussed above.

Using our model, we internally calibrate financial integration parameters by matching the observed data moments on financial institutions' cross-border financing for each country with the corresponding moments generated by the model. We calibrate the model parameters separately 
for the time period before the financial crisis and the time period after the financial crisis. The calibrated haircuts are consistent with the change in capital stock and the average foreign investment share in each country between our two periods of interest, 200-2007, and 2008-2011. We find a 54.3\% increase in estimated financial frictions in Continental Europe since the financial crisis. These two sets of calibration exercises yield two sets of parameters that govern the degree of financial integration and the real side of the economy before and after the financial crisis. To test the external validity of our model and calibrated financial frictions, we compare the level of investment per country produced by the model with the data, the calibrated financial frictions with those obtained in the literature (Fernández, Klein, Rebucci, Schindler, and Uribe, 2015), and model-generated current account levels in each country with those in the data.

After calibrating the model, we conduct two counter-factual experiments to measure the effects of changes in financial integration on aggregate output. The first experiment estimates the effect of supply side frictions due to financial separation since the crisis. In order to quantify the effects of financial disintegration on output and investment, we compare the pre-financial crisis world with a counter-factual world where the financial integration level is that of the post-financial crisis world. The results show that financial disintegration leads to a 0.54 percentage point (pp) drop in output in continental European countries since the financial crisis. In terms of consumption equivalence, the aggregate welfare loss for European economies is 0.20 percentage point due to financial disintegration. We also evaluate the effects of a fully integrated financial system by comparing the calibrated model economies with a counterfactual scenario where the countries are fully integrated financially. In this case, the additional output is $0.37 \mathrm{pp}$. In terms of consumption equivalence, welfare gains would be an additional $0.81 \mathrm{pp}$ of consumption compared to that in the pre-crisis period.

Our paper evaluates the change in barriers to financial integration since the European crisis. We attribute the increase in home bias in assets to a change in this financial friction which is quite similar to the works in international trade that evaluate the role of trade frictions in the increase in home bias in trade in the Great Trade Collapse (See Alessandria, Kaboski, and Midrigan, 2010a,b, 
2013). An important alternative explanation could be that business cycles or asset returns have become more synchronized since the Great Recession. This has lowered the returns to diversification. ${ }^{10}$ It is noteworthy that despite a steady trend of increasing cross-country asset correlation over the last two decades, cross-border allocation of capital was rising as well for more than a decade until the financial crisis (Figure 1(b)). Cross-country asset correlation have continued to increase since the crisis following the two-decade trend while cross-border allocation of capital has not. Hence, this alternative explanation does not seem to be able to explain the sharp change in cross-border capital flow since the crisis. ${ }^{11}$

Our work relates to the extensive literature in global banking. Peek and Rosengren (2000) have demonstrated the transmission of shocks from Japan to U.S. through U.S. branches of Japanese banks. Goldberg (2009) notes that foreign banking institutions play an important part in the global transmission of shocks due to their size. Cetorelli and Goldberg (2012a,b) discuss the importance of internal capital markets of global banking conglomerates as a channel for transmission of financial shocks during the financial crisis. Seminal research including Cole and Obstfeld (1991); Backus, Kehoe, and Kydland (1992); Stockman and Tesar (1995) has discussed the benefits from hedging aggregate shocks through holding foreign investments. Aviat and Coeurdacier (2007); Niepmann (2013, 2015); Fillat, Garetto, and Oldenski (2015) investigate capital allocation decisions of multinational corporations including banks and identify non-diversification motives of investment. Fillat, Garetto, and Goetz (2016) develop a rich structural model of entry into global banking with the regulatory framework in the U.S. driving the set of assumptions. Their paper helps understand the relationship between market access, capital flows, regulation, and entry. Our paper also focuses on the optimal capital allocation problem of financial institutions to estimate the effect of financial frictions.

\footnotetext{
${ }^{10}$ Cross-country asset correlations have been increasing over time, and an increase in cross-country correlation should lead to a reduction in diversification benefits. See Lewis (2006); Quinn and Voth (2008); Christoffersen, Errunza, Jacobs, and Langlois (2012). This phenomenon has been ongoing for the last two decades.

${ }^{11}$ Quinn and Voth (2008) who investigate a century of global market equity correlations also find that that reduction in barriers has been the driving cause of growing correlations during the last quarter century, though increasing correlated economic fundamentals also matter.
} 
Our paper also contributes to the literature on the impact of financial institutions on the real economy. Starting with the seminal papers by King and Levine (1993a,b), a literature that includes Beck, Levine, and Loayza (2000), among others, has shown that financial intermediaries can promote economic growth. The literature has also established that financial integration and competition between banks help economic growth as they help with greater entry of small businesses (See Jayaratne and Strahan, 1996; Cetorelli and Strahan, 2006; Kerr and Nanda, 2009). Rice and Strahan (2010); Gopalan, Udell, and Yerramilli (2011) suggest a general improvement in bank credit supply at better rates in the presence of bank competition and financial integration. Jermann and Quadrini (2012) show that financial shocks contributed significantly to the observed dynamics of real and financial variables of firms during the recent financial crisis. Our paper shows that financial frictions in terms of cross-border financing can have a significant effect on the real economy.

Furthermore, our work is related to the research that considers the impact of international trade and financial frictions on real allocations. Redding and Sturm (2008) provides evidence for the importance of market access for economic development. Alessandria et al. (2013) show that trade wedges can reflect the decisions of importers to change their inventory holdings. Caliendo and Parro (2015) quantify the trade and welfare effects from tariff changes due to NAFTA. Alessandria, Choi, Kaboski, and Midrigan (2015) study the question of causation between micro volatility and business cycles. Our paper relates to this literature as we quantify the real effects of supply side frictions due to the financial disintegration of European countries.

The rest of the paper is organized as follows. Section 2 describes the economic background in Europe and our datasets. Section 3 introduces the model. Section 4 discusses the calibration and the numerical methods used for the model solution. Section 5 discusses the numerical results and counterfactual estimates. Section 6 concludes. 


\section{Financial Integration in Europe}

This section first provides a background in the evolution of financial integration in Europe. It then discusses cross-border regulatory policies that may have contributed to financial disintegration in Europe since the crisis. These policies were implemented to reduce the risk of financial contagion.

\subsection{Financial Integration over Time}

Financial integration worldwide and in Europe, in particular, was growing for the last three decades before the financial crisis. Cross-border financing in Europe had tripled as a fraction of GDP from the year 2000 to the year 2007, to approximately six trillion Euros or 45\% of the GDP (See Figure 1(a)). To investigate how cross-border financing changed in European countries around the financial crisis, we utilize data from the Bank for International Settlements (BIS). Details regarding the data are in Appendix A.

Table 1 reports the ratio of stock of cross-border claims against domestic firms as a fraction of stock of total claims outstanding by all financial institutions (domestic and cross-border) against the firms in the respective country. The table shows significant variation in cross-border financing across countries and shows a significant decline worldwide after the crisis. ${ }^{12}$

\subsection{Banking Regulation and Financial Frictions}

Achieving an integrated financial capital market is a core ambition of the European Union. However, during the financial and sovereign debt crises, financial integration allowed capital to move swiftly across political boundaries in a manner that policy makers found destabilizing. Fears of "sudden stops" similar to earlier crises in Mexico in 1994, and East Asia in 1997 revived previous discussions regarding the costs of financial integration (Calvo, 1998; Chang and Velasco, 2001). In response to the crisis, central banks and policymakers worldwide first stabilized the financial

\footnotetext{
${ }^{12}$ While major economies such as the U.S. can withstand this financial separation more easily due to a very large domestic capital market - indeed cross-border financing had only risen to $16.5 \%$ in the U.S. and has now fallen to $11.9 \%$ - this is a larger concern for the European economies where trade and labor markets remain integrated but financial markets face significant disintegration post-crisis.
} 
system and since then have focused their attention on ensuring that systemically important financial institutions are better capitalized and have a clear recovery and resolution plan. In addition, the European Systemic Risk Board (ESRB) has been entrusted with a macro-prudential oversight function in Europe. The corresponding institution in the U.S. is the Financial Stability Oversight Council.

To ensure financial stability, after the financial crisis the European Commission implemented a series of policy reforms including cross-border banking regulation overhaul: (i) Consultations on the reorganization and resolution of credit institutions began immediately in December 2007, which included studying how to ensure transition of assets within a cross-border financial institution. $^{13}$ (ii) In addition, Basel II and Basel III capital requirements have been phased in since the financial crisis. ${ }^{14}$ (iii) Furthermore, in February 2012, the Liikanen commission was established to determine whether, in addition to ongoing regulatory reforms, structural reforms of the EU financial institutions would strengthen financial stability and improve efficiency and consumer protection, and, if so, to make proposals as appropriate. (iv) Separately, public consultation regarding an EU framework for "Cross-Border Crisis Management in the Banking Sector" began in October 2009. The commission agreed to avoid reliance on taxpayers to stop financial contagion in the future. The objective of the reform is to create a number of lines of defence against a future financial crisis that include (a) greater prevention and early intervention, (b) better resolution tools and cross-border coordination, and (c) resolution funds. ${ }^{15}$

The resolution fund to finance orderly winding up of financial institutions, a key element of the resolution mechanism, remains at the national level. The commission recognized the importance of setting up a single pan-EU fund but pointed to political frictions that make a pan-EU fund or even further, a global fund, infeasible. Needless to say, if countries are expected to set up their

\footnotetext{
${ }^{13}$ See European Commission summary of initiatives on winding-up of credit institutions at http://ec. europa. eu/finance/bank/windingup/index_en.htm.

${ }^{14}$ See http: //www . bis.org/publ/bcbsca.htm for details on Basel reforms and regulatory framework chronology.

${ }^{15}$ See European Commission Communication at http://europa.eu/rapid/press-release_MEMO-10-214_ en.htm?locale=en.
} 
own resolution funds for their institutions, then a moral hazard problem emerges (Holmstrom, 1982). National policymakers' support for taking cross-border risks declines. This is because the taxpayers of one country do not wish to insure the financial sector of their country against risks it takes abroad, as they will be fully internalizing the risks in the case of crisis, but not the rewards in the case of prosperity, of such cross-border financing.

In sum, a number of policy initiatives have been adopted to reduce the deleterious effects of future financial contagion. However, they have also increased cross-border financial frictions (Barth, Gerard Caprio, and Levine, 2013; Fernández et al., 2015; Forbes, Reinhardt, and Wieladek, 2016). Fernández et al. (2015) create a new dataset of capital control restrictions over the last two decades using the analysis in the Annual Report on Exchange Arrangements and Exchange Restrictions (AREAER) of International Monetary Fund (IMF). ${ }^{16}$ Figure E.5 in the Appendix reports the overall restrictions index in the 14 European Countries in our sample for which Fernández et al. (2015) (FRU) report their measure. ${ }^{17}$ As can be seen, there has been a significant increase in capital control restriction in recent years. The dataset shows that these restrictions may have started even a bit earlier that the financial crisis. After the financial crisis, these frictions have stayed in place. Forbes et al. (2016) argue that increases in microprudential capital requirements tend to reduce international bank lending and some types of unconventional monetary policy can amplify this effect. The authors show in particular that the UK's Funding for Lending Scheme (FLS) significantly amplified the effects of increased capital requirements and reduced external lending.

The financial crisis provided the counterpoint to the benefits of financial integration that drove policy before the crisis: the possibility of financial contagion leading to a "doom loop" (See Farhi and Tirole, 2014, among others). This paper does not focus on the costs to the economy due to possible systemic risk but focuses on the costs to the economy from lesser financial integration. Answering the question of whether such costs are justified by the potential gains from avoiding

\footnotetext{
${ }^{16}$ The AREAER reports the presence of rules and regulations for international transactions by 10 asset categories. The authors use the narrative description in the AREAER to determine whether or not there are restrictions on international transactions, with 1 representing the presence of a restriction and 0 representing no restriction.

${ }^{17}$ Luxembourg is not in the dataset of Fernández et al. (2015).
} 
future contagion, is beyond the scope of this paper. The question, however, is an important tradeoff that policymakers must consider (See Stein, 2009, for a discussion of benefits and costs of capital regulation on market efficiency).

\section{The Model}

The main problem of interest is the allocation of capital across countries by financial institutions. This section first discusses the representative household and the representative firm. We then introduce the financial institution's problem and define the equilibrium.

\subsection{Household}

There are $N$ countries in the economy. At the beginning of a period, representative households in country $i \in\{1, \ldots, N\}$ have $s_{i}$ units of savings. They invest the savings in the financial institution of their country, for which they receive return $r_{i}$ per unit savings at the end of the period. Households also supply one unit of labor inelastically at wage $w_{i}$. Uncertainty in the model is driven by the country-specific productivity shocks $A_{i}$. Both $r_{i}$ and $w_{i}$, which depend on $A_{i}$, are stochastic and vary by country. The amount of savings $s_{i}$ varies by country $i$ as well. The number of households $L_{i}$ in each country is also allowed to be different to capture heterogeneity in sizes of European countries. Total savings in a country $i$ is therefore $S_{i} \equiv s_{i} L_{i}$.

At the end of the period, households of country $i$ consume the return $r_{i}$ from their savings $s_{i}$ and their wages $w_{i}$. Households' consumption $c_{i}$ is given as follows:

$$
c_{i}=w_{i}+r_{i} s_{i}
$$

The assumption of no new savings allows us to keep the household problem static. Our static model also assumes that there is investment at the beginning and consumption out of output at the end of the period. A dynamic model with consumption and investment in every period would certainly be better. Since we are interested in a relatively short period of time, and since the model solution has a large dimensionality from the number of countries in the EU countries, we believe 
tractability justifies these assumptions.

\subsection{Financial Institutions's Problem and Financial Integration}

In this model, the representative households of each country simply invest their savings in the domestic financial institution of their own countries. We assume that the financial institution in country $i$ is owned by the households of the same country. The financial institution then allocates the capital across the countries to maximize expected utility for their owners (Diamond, 1984; Eaton, 1994; Niepmann, 2015; Fillat et al., 2016). ${ }^{18}$ Even though we refer to a financial institution in the model, in the end, we are building a multi-country model of capital flows in which most bilateral flows are driven by the pursuit of higher returns and diversification of risk.

Let $R_{i j}$ denote the gross investment returns a financial institution in country $i$ obtains when investing in country $j$ and let $\phi_{i j}$ be the share of assets of a financial institution in country $i$ investing in country $j$. We impose the no-short-selling constraint that requires all $\phi_{i j}$ to remain non-negative, $\phi_{i j} \geq 0 .{ }^{19}$ The financial institution's problem in country $i$ is to maximize the expected utility of the representative household, subject to the budget constraint (Eq. 1), a constraint that allocation fractions across the countries add up to unity, and the no short sale constraint. Thus, the financial

\footnotetext{
${ }^{18}$ We are making an assumption, needed for general equilibrium in terms of capital allocation, that these 15 countries constitute a closed economy. See Appendix B for a discussion of this assumption. To be additionally conservative, in our counterfactual experiments, we will exclude Great Britain, Ireland, and Luxembourg. The first two countries have economies that are more connected across the Atlantic Ocean with the U.S. and the Commonwealth nations. The last country is a financial center. This is even though we estimate the model with all 15 countries. This will ensure that we capture impact of financial frictions in Continental Europe and not financial frictions that, say, affect capital flow to Great Britain and Ireland from the U.S.

${ }^{19}$ Short selling is not economically meaningful in our setup. $\phi_{i j}<0$ effectively will mean that country $i$ is investing a negative share of savings in country $j$, or in other words borrows from country $j$. We can achieve the same net capital flows between countries $i$ and $j$ by having a positive investment from country $j$ to country $i, \phi_{j i}>0$, while keeping our no-short-selling constraint, $\phi_{i j} \geq 0$. Further, we do not observe negative investment shares in the data.
} 
institution's problem is characterized as follows:

$$
\begin{aligned}
\max _{\Phi_{i} \equiv\left\{\phi_{i 1}, \ldots, \phi_{i N}\right\}} \mathbb{E} u\left(c_{i}\right) \\
\text { s.t. } c_{i}=w_{i}+\Phi_{i}^{\prime} R_{i} s_{i}, \\
\phi_{i i}+\sum_{j \neq i} \phi_{i j}=1, \\
\phi_{i j} \geq 0, \quad \forall i, j .
\end{aligned}
$$

where $\Phi_{i}=\left\{\phi_{i 1}, \ldots, \phi_{i N}\right\}$ is the vector of portfolio allocation and $R_{i}=\left\{R_{i 1}, \ldots, R_{i N}\right\}$ is vector of returns, and the expectations are taken over the joint distribution of the vector of $\left\{A_{1}, \ldots, A_{N}\right\}$. Thus, the final return of the household on total savings is $r_{i}=\Phi_{i}^{\prime} R_{i}$. We assume that the household utility function is CRRA:

$$
u(c)=\frac{c^{1-\gamma}}{1-\gamma}
$$

where $\gamma$ is the risk aversion coefficient of the household.

Returns on domestic investment in country $i, R_{i i}$, are endogenously determined based on supply of capital $K_{i}$, labor force available $L_{i}$, productivity $A_{i}$ and wages $w_{i}$ (Eq. 4 discussed next in the firm's problem). The financial institution's cross-border returns $R_{i j}$ depend on country $j$ 's domestic investment return $R_{j j}$ and the level of financial integration of country $j$. As in Gertler and Kiyotaki (2010); Gertler, Kiyotaki, and Queralto (2012), financial institutions invest in firms by purchasing productive capital.

Financial frictions due to limited financial integration are captured by parameter $\theta_{j}$ that varies across countries. The parameter $\theta_{j}$ in effect captures the "haircut" on (i.e., reduction in) investment return from country $j$ due to levels of financial integration of the country. The rate of crossborder investment return in country $j$ for financial institutions in country $i$ depends upon destination country $j$ 's level of financial integration:

$$
R_{i j}=R_{j j} e^{-\theta_{j}}, \quad \forall i, j
$$


where the investment rate $R_{j j}$ for each country $j$ is endogenously determined based on demand of capital from firms in the country and supply of capital from households who can choose among countries. These endogenous returns together with the variance-covariance matrix of TFP shocks generate capital flows in the model. These capital flows will be matched to those observed in data using internally calibrated destination-specific haircuts, i.e. $\left\{\theta_{1}, \ldots, \theta_{N}\right\}$. When country $j$ is fully financially integrated with the rest of countries, $\theta_{j}=0$; and when country $j$ 's capital market is completely isolated from the rest of the economies (i.e., $\theta_{j} \rightarrow \infty$ ), investors can not earn any return from their investment in country $i$, i.e. $R_{i j}=0$. In such an extreme case, no capital should flow into the country and the foreign share of investment is 0 . Cross-border investments may be more beneficial as regulatory frictions decline (Houston, Lin, and Ma, 2012).

Note that the financial frictions in our setup are only destination specific financial frictions. A more general approach is to allow for source and destination financial frictions separately. Our choice of only destination specific financial frictions is partially driven by computational limitations. Further, if the capital flow is intermediated through a third country, the destination financial frictions will still capture them. However, we feel satisfied with this assumption because as we will see later in Section 4.3, the calibrated financial frictions correlate strongly with those obtained by Fernández et al. (2015) in their work on capital control.

\subsection{Firm's Problem}

The representative firm in country $i$ enjoys productivity $A_{i}$ and faces local wage $w_{i}$ and capital rental rate $R_{i i}^{f}$. The firm is assumed to have Cobb-Douglas production function, and maximizes profits $\pi$ by choosing rented capital $K_{i}$ as follows:

$$
\pi_{i}=\max _{K_{i}} A_{i} K_{i}^{\alpha_{i}} L_{i}^{1-\alpha_{i}}-w_{i} L_{i}-R_{i i}^{f} K_{i}
$$

where $A_{i}$ is the aggregate productivity shock in country $i$ and $\alpha_{i}$ is the output elasticity of capital.

Let $A=\left\{A_{i}, \ldots, A_{N}\right\}$ be the vector of productivity shocks for all $\mathrm{N}$ countries. We assume that 
$A$ follows a multivariate log-normal distribution as follows:

$$
A \sim \ln \mathcal{N}(\mu, \Omega)
$$

Here, we allow the productivity shocks between different countries to be correlated with each other. This correlation can create cross-country linkages of financial returns based on the real economy. In particular, if $\operatorname{cov}\left(A_{i}, A_{j}\right) \neq 0$, the productivity shocks between countries $i$ and $j$ are correlated. Thus, the representative financial institution in country $i$ may have an incentive to invest in country $j$ 's production in order to reduce the risk of the portfolio of a household in country $i$.

The rate of return for the financial institution that rents capital in country $i$ is:

$$
R_{i i}=1+R_{i i}^{f}-\delta_{i}
$$

where $\delta_{i}$ is the capital depreciation rate in country $i$.

\subsection{Equilibrium}

We consider an equilibrium where a representative financial institution in country $i$ makes the allocation decision regarding the share of domestic and foreign investment. Given the level of financial integration vector $\left\{\theta_{i} \mid i \in[1, N]\right\}$, and similarly productivity shocks $\left\{A_{i}\right\}$, deposits per capita $\left\{s_{i}\right\}$, labor supply $\left\{L_{i}\right\}$ and initial capital $\left\{K_{i 0}\right\}$ in each country $i$, the equilibrium consists of a cross-country distribution of financial institutions' asset allocation decisions, capital returns and firms' capital levels $\left\{\phi_{i 1}^{*}, \ldots, \phi_{i N}^{*}, R_{i i}^{*}, K_{i}^{*}\right\}$ and is defined as follows:

1. $\left\{\phi_{i i}^{*},\left\{\phi_{i j}^{*}\right\}_{j \neq i}\right\}$ solve banks' optimization problem as follows:

$$
\begin{array}{r}
\max _{\Phi_{i} \equiv\left\{\phi_{i 1}, \ldots, \phi_{i N}\right\} \geq 0} \mathbb{E} u\left(c_{i}\right) \\
\text { s.t. } c_{i}=w_{i}+\Phi_{i}^{\prime} R_{i} s_{i}, \\
\phi_{i i}+\sum_{j \neq i} \phi_{i j}=1
\end{array}
$$


2. $\phi_{i i}^{*} s_{i} L_{i}+\sum_{j \neq i}^{N} \phi_{j i}^{*} s_{j} L_{j}+K_{i 0}\left(1-\delta_{i}\right)=K_{i}^{*}$ for every country $i$.

3. $w_{i}^{*}=\left(1-\alpha_{i}\right) A_{i}\left(K_{i}^{*}\right)^{\alpha_{i}} L_{i}^{-\alpha_{i}}$ for every country $i$.

4. $R_{i i}^{*}=1+\alpha_{i} A_{i}\left(K_{i}^{*}\right)^{\alpha_{i}-1} L_{i}^{1-\alpha_{i}}-\delta_{i}$ for every country $i$.

5. $R_{i j}^{*}=R_{j j}^{*} e^{-\theta_{j}}$ for every country.

Asset returns are determined in equilibrium based on supply of capital $K_{i}$, labor force available $L_{i}$, productivity $A_{i}$ and wages $w_{i}$ (Eq. 4). ${ }^{20}$ The incentives of the bank of country $i$ in the model are aligned with those of the households of the same country. ${ }^{21}$

\section{Calibration and Model Solution}

This section describes calibration details and equilibrium solution approach. To calibrate the model, as discussed in Section 2, we use the data from the Penn World Tables, the Bank of International Settlements and Lane and Milesi-Ferretti (2007). The original dataset in Lane and Milesi-Ferretti (2007) was extended to include the data up to 2011 by Lane and Milesi-Ferretti.

\subsection{External Calibration of Productivity and Demographic Parameters}

Table 2 reports the relevant statistics of the 15 countries in the European Union that we focus on. These 15 countries were in the European Union before the year 2000. Our sample selection ensures that we have a long enough time series prior to 2007 for each country and thus can calculate the variance and covariance matrix of their joint productivity. The data period covered is from 2000 to 2011. One year after the introduction of Euro in 1999, we consider the year 2000 to be a good

\footnotetext{
${ }^{20}$ One could use a partial equilibrium approach and utilize asset returns series over time directly. In such a case, a possibility would be that a partial equilibrium model may overestimate the returns from diversification given the exogenous nature of returns, and then also overestimate the financial frictions given that the data will not support the level of diversification estimated by the model with exogenous returns. Another issue is that given that cross-border capital flows are composed of multiple asset classes through multiple investor types, it is hard to convincingly calculate a correct measure of returns. Hence, we think using TFP data and allowing returns to be endogenous provides us a way to avoid these difficult questions.

${ }^{21}$ Exploring the impact of an incentive misalignment between households and financial institutions, specifically due to macro-prudential restrictions, is beyond the scope of this work.
} 
starting point. 2011 is the latest year for which data is available from Penn World Tables (PWT) 8.1.

We use the PWT 8.1 data for each country $i$ to obtain capital depreciation rate $\delta_{i}$, the share of labor compensation in GDP $\alpha_{i}$, the value of capital stock $K_{i}$, output in each country $Y_{i}$, investment level $I_{i}$ in each country. Labor supply $L_{i}$ is the product of the number of persons employed and the average annual hours worked by the employed person. We calculate the amount of savings $S_{i}$ in country $i$ using investment and current account data. The reason we do this is because not all capital stock may be available for reallocation to other countries, in a relatively short period of time. In a dynamic model, one could imagine all capital being able to freely move, but there would be a capital adjustment cost, and adjustment would be gradual. In our model, the amount of savings $S_{i}$ is not meant to be a measure of wealth but that of allocatable resources. Another possible approach to calibrating savings could have been capital stock plus net foreign assets adjusted for what portion of capital is available for cross-border reallocation. The value of initial capital in country $i$ is calculated as $K_{i 0}=\left(K_{i}-I_{i}\right) /\left(1-\delta_{i}\right) .{ }^{22}$ We calibrate TFP parameter for each country and each period as the residual in the production function, $A_{i}=Y_{i} /\left(K_{i}^{\alpha_{i}} L_{i}^{1-\alpha_{i}}\right)$. We also calibrate our parameters using an alternative approach, that we discuss in detail in Section 5. In the alternative approach, we take TFP as given and calculate the output for each country $Y_{i}$. The results remain quantitatively and qualitatively similar in that case as well. We normalize $Y_{i}$ and $L_{i}$ in 2005 in the Great Britain in our sample to 1. Additional details regarding variable construction are in Appendix A.

Table 2 summarizes our estimates of the parameter values for the two subperiods that we are interested in, 2000-2007 and 2008-2011. The table reports significant differences in the reported characteristics. The relative prosperity and productivity, with respect to the U.S., also varies significantly. Table E.10 in the Appendix reports the cross-country variance-covariance matrix of loga-

\footnotetext{
${ }^{22}$ As discussed in Section 3, the final rented capital observed in a country is the sum of initial capital available to the country and the sum of investments made by the resident financial institutions of all 15 European countries out of their savings. The resident financial institutions of each country, in turn, make those investments based on return-risk trade-off where return on capital is endogenously determined based on production function parameters of the target country and investments by other representative financial institutions of the other countries.
} 
rithm of TFP levels in the 15 European countries for the full sample period. It is notable that there is substantial variation in the variance of the logarithm of TFP levels across nations. Denmark has one of the lowest levels at 1.47 percentage points standard deviation, whereas Luxembourg which is an active conduit for allocation of capital within Europe has the highest reported level at 13.71 percentage points standard deviation. The German standard deviation of the logarithm TFP is almost half of that of France, at 3.87 percentage points standard deviation. The TFPs in most economies are positively correlated, which is expected, with the only exception being Portugal and Denmark. Among the larger economies, the German TFP is more correlated with that of Great Britain (0.70) than of France (0.35). The TFPs of Italy and Spain are even less correlated with that of Germany, having correlations of 0.21 and 0.23 respectively.

\subsection{Equilibrium Solution Algorithm}

The optimal allocation of capital for each country is dependent on the optimal allocation of the capital of all other $N-1$ countries, where $N=15$ countries in our case. This is because the return on investment is dependent on total capital invested, which is dependent on the allocation of other countries. In other words, every country is allocating across $N$ countries based on a $N \times N$ variance-covariance matrix of productivity shocks, and based on the $N \times 1$ return vector for each

country which is dependent on allocation of capital of other countries into the target country and the haircut faced by each country in investing in the target country.

Given the model parameters, we find the equilibrium of the model by solving the system of equilibrium conditions that consist of the first-order optimality conditions for the financial institu- 
tions and market-clearing conditions:

$$
\begin{aligned}
& s_{i} \mathbb{E} u^{\prime}\left(c_{i}\right)\left(R_{i j}-R_{i N}\right)+\lambda_{i j}-\lambda_{i N}=0, \quad \forall i, j, \\
& \lambda_{i j} \phi_{i j}=0, \quad \lambda_{i j} \geq 0, \quad \phi_{i j} \geq 0, \quad \forall i, j, \\
& c_{i}=w_{i}+\Phi_{i}^{\prime} R_{i} s_{i}, \quad \forall i, \\
& \phi_{i i}+\sum_{j \neq i} \phi_{i j}=1, \quad \forall i, \\
& \phi_{i i}^{*} s_{i} L_{i}+\sum_{j \neq i}^{N} \phi_{j i}^{*} s_{j} L_{j}+K_{i 0}\left(1-\delta_{i}\right)=K_{i}^{*}, \quad \forall i, \\
& w_{i}^{*}=\left(1-\alpha_{i}\right) A_{i}\left(K_{i}^{*}\right)^{\alpha_{i}} L_{i}^{-\alpha_{i}}, \quad \forall i, \\
& R_{i i}^{*}=1+\alpha_{i} A_{i}\left(K_{i}^{*}\right)^{\alpha_{i}-1} L_{i}^{1-\alpha_{i}}-\delta_{i}, \quad \forall i, \\
& R_{i j}^{*}=R_{j j}^{*} e^{-\theta_{j}}, \quad \forall i, j .
\end{aligned}
$$

This system includes the budget constraints and market clearing conditions from Section 3.4, and the first-order conditions that describe the solution to the investment allocation problem of the representative financial institutions. Because of the presence of the short-selling constraints (we allow representative banks to take only non-negative positions in member countries), these firstorder conditions take the form of the Kuhn-Tucker inequalities, with $\lambda_{i j}$ denoting the corresponding Kuhn-Tucker multipliers. We use Zangwill and Garcia (1981) approach to replace the KuhnTucker inequalities with equations by an appropriate change of variables, and solve the resulting system of non-linear equations, given the values of $\theta_{j}{ }^{23}$

Given the high dimensionality of the problem, we approximate the expectations in the system of equilibrium conditions specified above using monomial integration rules which were introduced by Judd (1998) to economics literature, and described in detail in Maliar and Maliar (2014). For a given vector $\mu$ and matrix $\Sigma$ which, given our assumption of log-normality, fully characterize the distribution of $\left\{A_{1}, \ldots, A_{n}\right\}$, monomial integration rules construct a relatively small set of nodes and

\footnotetext{
${ }^{23}$ See Appendix C for more details.
} 
weights distributed within a multidimensional hypercube. The computational expense of monomial rules grows polynomially with the dimensionality of the problem, which makes them ideal for problems of large dimensions such as the present one.

The equilibrium solution output is a matrix of allocation of capital by all countries in all other countries conditional on certain haircuts. The calibration of these financial frictions is discussed in Section 4.3.

\subsection{Internal Calibration of Financial Friction Parameters}

We calibrate destination-specific haircuts (i.e., financial frictions $\left.\left\{\theta_{1}, \ldots, \theta_{N}\right\}\right)$ that can justify the observed post-crisis capital flows for each country by targeting moments on the share of foreign investments before and after the financial crisis. Table 1 reports for each country and each year the gross cross-border financing that the country receives and claims outstanding in a certain year as a fraction of the sum of total claims outstanding in terms of lending by domestic financial institutions and gross cross-border financing. Data used to calculate the fractions are obtained from the BIS as described in detail in Section 2.

To calibrate the $N \times 1$ vector of financial frictions which generate $N \times 1$ optimal foreign investment shares for $N$ countries, we utilize a fully parallelizable global optimization algorithm as suggested in Guvenen (2011). The algorithm combines a global search stage with a local stage. The algorithm uses the Sobol sequence to obtain a series of "quasi-random" starting points for the global search stage. Then it conducts a local search from that starting point using the NelderMead's downhill simplex algorithm. A Sobol sequence provides a way to search thoroughly and at the same time, efficiently across the parameter space of frictions. The algorithm can be easily parallelized by allowing each central processing unit core to do a separate local search. To reduce the dimensionality of the problem, and to have an exact match in terms of moments, we keep the haircuts $e^{-\theta_{i}}$ equal for a target country irrespective of which country is investing into it. For example, the haircut faced by a German financial institution and a French financial institution on their investments in Greece is the same. ${ }^{24}$

\footnotetext{
${ }^{24}$ Ideally, we would like to match bilateral flows for the $15 \times 15$ matrix of countries. However, we do not have
} 
The first column of Table 3 reports the calibrated financial frictions $e^{-\theta_{i}}$ after the financial crisis using our model and data. The second and third columns of the table compare model simulated moments and targeted moments from data. The average values for the period 2008-2011 are reported in the "Data" column of Foreign Shares panel. We note that the data moments regarding the foreign share of total investment is well matched by the model generated moments. On average, the model tracks foreign investment shares in the data within $0.68 \%$. The reported distance is calculated as a sample standard deviation. As an out of sample test, we also tabulate the model generated aggregate investment level in a country and the data on investment obtained from PWT 8.1. As seen in the fourth and fifth columns in Table 3, our model predicted aggregate investment shares closely track the corresponding moments in the data.

To test the external validity of the estimated financial frictions, we utilize an index of overall restrictions created by Fernández et al. (2015). Fernández et al. (2015) creates a dataset of capital control restrictions on both the inflows and outflows of 10 categories of assets for 100 countries over the period of 1995-2013. We find that, for the post-crisis sample period of 2008-2011 in continental Europe ${ }^{25}$ the cross-sectional correlation between the overall restrictions index and our estimated financial frictions is 22.9 percent. Figure 3 reports the correlations. The two vectors are demeaned before calculating correlation. Luxembourg is not in the dataset of Fernández et al. (2015), and hence is excluded in the reported correlation. We also exclude Portugal which has a very high capital control index number compared to Spain, even though our estimates suggest Spain and Portugal are similar in terms of capital control. GDP weighted cross-sectional correlation estimate is 0.787 , as shown in the right panel of Figure 3.

access to the matrix of bilateral ratios for each country, we only have aggregate data separated at foreign/domestic level. Hence, we do not have enough moments available for matching bilateral flows. Further, it is computationally much more challenging to expand the set of moments from 15 to 225 . Because of this limitation on the number of moments matched, we cannot be confident that the model does a good job matching bilateral flows - we can only speak to cross-border flows aggregated at the country level.

${ }^{25}$ As discussed earlier, we exclude the Great Britain, Ireland and Luxembourg in the counterfactuals in the next section, and hence we exclude them in the external validity test as well. This is even though we estimate the model with all 15 countries. This approach ensures that we capture the impact of financial frictions in continental Europe and not financial frictions that affect capital flow to Great Britain and Ireland from, say, the U.S., as the two island nations are relatively more connected to the U.S. and the Commonwealth nations. A similar reason applies for Luxembourg which is a financial center within Europe. 
As another supporting evidence for the model, we calculate the correlation of the model generated current account numbers with those obtained from data at the beginning of the period. The correlation between model generated current account numbers and data is 0.692. Given that Greece was facing unique economic challenges during this period, we also calculate the correlation without Greece, which is 0.696. Note that investment level moments and therefore current account moments were un-targeted. ${ }^{26}$

\subsection{Change in Financial Frictions from Before to After the Crisis}

This section investigates how calibrated financial friction changed over time. To answer this question, we also calibrate the financial frictions for the pre-2007 period, i.e. the period before the financing crisis. Table 4 shows the calibrated frictions before the financial crisis and those calibrated post financial crisis. The next two columns also show the change in financial frictions post-crisis with equal weights and with GDP weights respectively. We note that overall financial frictions have increased between the two periods. This supports findings in the literature on capital controls (Fernández et al., 2015).

The GDP weighted $e^{-\theta}$ for European countries pre-crisis is 0.9831 , and post-2007 is 0.9739 . The friction in this case is $1-e^{-\theta}$, which is the loss due to limited financial integration. Therefore, the haircut increases from $1.69 \%$ to $2.61 \%$ from before the financial crisis to after the crisis. This is a $54.3 \%$ increase in financial frictions post crisis. ${ }^{27}$

As we see, the standard deviation in haircuts on investment returns are approximately 2.43 percent before the crisis and 1.68 percent after the crisis for the continental European countries (except Luxembourg). This shows the significant importance of financial frictions, which with such limited variation are able to generate large effects on output, as Section 5 shows next. It is important to note that cross-sectional variation is important for allocation of capital within the

\footnotetext{
${ }^{26}$ Our experiment is intended to match reasonably well the current accounts at the beginning of the period essentially by construction. Table D.9 in Appendix D shows that, as expected, the difference between the current account generated by the model and the current account from the data is equal to the negative of the difference between the investment in the model and in the data.

${ }^{27}$ This number is calculated as $\frac{1-e^{-\theta} P_{\text {Ost }}}{1-e^{-\theta} P_{\text {Pre }}}-1=0.543$.
} 
period, but at the same time change in financial frictions from the pre-crisis period is important for determining the overall impact of financial frictions on the economy.

\section{Counterfactual Experiment Results}

We conduct two counterfactual experiments to measure the benefits of reduction in supply side frictions due to financial integration.

\subsection{Impact of Financial Disintegration on European Recovery}

In order to quantify the effects of financial integration on outcomes and capital investment, we compare the pre-financial crisis world with a counterfactual world where the financial integration level is that of the post-crisis level $\Theta^{\text {post-2007 }}$ and the real side of the economy remained at the pre-crisis level $\left\{\alpha^{\mathrm{pre-2007}}, A^{\mathrm{pre-2007}}, \delta^{\mathrm{pre-2} 2007}, L^{\mathrm{p} r e-2007}, S^{\mathrm{pre-2} 2007}, K_{0}^{\mathrm{p} r e-2007}\right\}$. The difference in outputs between these two scenarios measures the real effects of changes in financial integration. The reason we conduct this counterfactual as opposed to the opposite where we take estimated financial frictions from the pre-2007 period and use the data from the post-2007 period is because significant economic and regulatory interventions were conducted post financial crisis. The pre-2007 period data is relatively more undisturbed. Further, we are interested in financial frictions from the post-2007 period, some of which have been imposed by regulatory authorities themselves through "ringfencing" of economies. Hence, applying net frictions calibrated from the post-crisis period on the undisturbed pre-crisis period economic data is the appropriate exercise in our opinion.

Panel A of Table 5 reports the results. The first counterfactual reports the output (Y), wage (W) and return on capital (R) for continental European economies if they faced the same financial frictions as before the financial crisis. The financial frictions have been calibrated using the model and data from the post-financial crisis period as described in Section 4. The results reported are scaled versions of the same characteristics for each country in the pre-crisis period. We focus on continental Europe in the counterfactuals because the United Kingdom is a major financial center and Ireland has been going through structural changes over the last decade. Further, the two English-speaking island nations are relatively more connected to the U.S. and the Commonwealth 
nations. Therefore, capital from around the world flew into these countries before the crisis and left after the crisis. This is not the case in continental Europe which is more or less a closed economy. We also drop Luxembourg because it is a financial center within continental Europe.

Overall, Panel A of Table 5 shows that if financial frictions post-crisis existed in the pre-crisis period, all else being equal, the GDP of continental European countries (ex-Luxembourg) will be 0.54 pp lower. ${ }^{28}$ This estimate is in line with other estimates of the impact on GDP of banking sector overhaul (See, for example Slovik and Cournéde, 2011, who estimate that the impact of Basel III on GDP growth is between -0.05 to -0.15 percentage point). All else being equal includes pre-2007 levels of depreciation rate, labor, TFP, output elasticity of capital, initial capital available to each country, and investable savings (See Panel A of Table 2). In addition, labor wages would have been 0.72 percentage lower across continental Europe before the financial crisis if the same level of financial frictions as those calibrated post-financial crisis existed. The marginal product of capital would also have been 0.71 percent lower.

Focusing on individual countries, the GDP of Germany, which is 27 percentage of the continental European economy in our data period, would have been 1.02 percentage lower. France, with 19 percent of the continental European economy, would have suffered a 0.25 percentage lower output. Greece, a country that faced a significant uncertainty post-financial crisis regarding its future in Europe, would have suffered a 0.63 percentage lower output if similar financial constraints existed before the crisis. However, the aggregate results are GDP-weighted and thus are not driven by Greece, which is only 2.6 percent of the European output in our sample.

\subsection{Benefits of an Integrated Financial System}

In this counterfactual experiment, we evaluate the effects of a fully integrated financial system by comparing the calibrated model economies with a counterfactual scenario where all countries are fully integrated financially. We implement this counterfactual simulation by setting $\theta_{i}=0$ for every

\footnotetext{
${ }^{28}$ Table E.11 in the Appendix shows that the average GDP growth rate for the post-crisis period (2008-2011) is effectively zero. It also shows that the growth rate of the continental European Union countries has been approximately $2.39 \%$ percentage points per year for the two-decade period of 1991-2011.
} 
country $i \in\{1, \ldots, N\}$. When $\theta_{i}=0$, country $i$ is fully integrated with the rest of the European Union countries. In other words, there are no haircuts due to financial frictions $\theta$ on investment returns for any financial institution residing in any country, irrespective of the investment being domestic or foreign. The difference in outputs between an integrated Europe with $\theta_{i}=0$ and the actual European data provides an estimate of the gains from financially integrative policies.

Panel B of Table 5 reports the results of the counterfactual economy where there are no haircuts for cross-border financing. The panel shows that if financial frictions could be eliminated in the pre-crisis period, all else being equal, the GDP of continental European countries would have been 0.37 pp higher. As before, all else being equal includes pre-2007 levels of depreciation rate, labor, TFP, output elasticity of capital, initial capital available to each country, and investible savings (See Panel A of Table 2). In addition, labor wages would have been 0.26 percentage higher across continental Europe before the financial crisis in an economy with a completely integrated financial system. The marginal product of capital would also be higher by 0.22 percent.

In contrast to the case when post-crisis financial frictions have hurt Germany, which is the largest economy in continental Europe, if financial frictions are eliminated, we find that Germany per se is not a major beneficiary (it gains 0.03 percentage point in output). However, French output increases by 0.77 percentage point and Spanish economic output increases by 90 basis points.

\subsection{Welfare Effects of Financial Frictions}

Sections 5.1 and 5.2 discussed the costs of financial disintegration and benefits of financial integration in terms of output. In this section, we estimate the welfare effects of these two counterfactuals. The approach we utilize is similar to that in Conesa, Kitao, and Krueger (2009). Specifically, we ask the following question: by what percentage $g$ do we have to change consumption in the benchmark case, where benchmark consumption is given by $c_{B}$ for the household to be indifferent between living in the benchmark case and living in the counterfactual case where consumption is $c_{C F}$. This percentage $g$ in our case given a CRRA utility function is given by:

$$
g=\left[\frac{u\left(c_{C F}\right)}{u\left(c_{B}\right)}\right]^{\frac{1}{1-\gamma}}-1,
$$


where risk aversion coefficient $\gamma=2$.

Table 6 reports the welfare consequences in terms of consumption equivalence described above. Columns (1) and (3) report the ratio of un-weighted and GDP-weighted consumption (in percentage) lost due to financial frictions that were imposed in the post-crisis period. Columns (2) and (4) report consumption equivalent gains compared to the pre-crisis benchmark consumption in case that financial frictions could be completely eliminated. Column (3) of the table shows that in terms of consumption equivalence, the aggregate welfare effect on European economies is 0.20 percentage point. The benefits of eliminating financial frictions are reported in the final column at 0.81 percentage points in terms of consumption in the pre-crisis period.

\subsection{Robustness Tests}

This section conducts two robustness tests with alternative time periods and productivity measure.

\section{Change in Financial Frictions from the Financial Crisis till 2015}

Section 4.4 calibrates two frictions for each country (pre-2007 and 2007 to 2011). An important concern may be that choice of periods may understate the change in barriers. The change in foreign investment from 2007 to 2015 is possibly larger than the change from the pre-2007 to post-2007 periods. To address this concern, this section makes a comparison of the 2006 to 2008 period with the 2011-15 period regarding financial frictions and output. ${ }^{29}$

Table 7 reports the estimated frictions in years 2006-08 and those estimated in years 2011-15. The next two columns report the change in financial frictions for years 2011-15 with equal weights and with GDP weights respectively. The haircut increases from $2.42 \%$ to $3.18 \%$ from $2006-08$ to years 2011-15, a 31.2 percent increase in financial frictions. The estimated financial friction for the 2011-15 is higher than that of the pre-2007 period in Section 5.1. The final column reports the output (Y) for continental European economies (except Luxembourg) if they faced the same financial frictions as in period 2011-15 in years 2006-08. It shows that had the financial frictions

\footnotetext{
${ }^{29}$ One issue that we face is that while we have cross-border financing data available for 2011-2015, the economic data from Penn World Tables 8.1 and Lane and Milesi-Ferretti (2007) stops in 2011. Therefore we use 2010-11 economic data and 2011-15 financial data for the exercise.
} 
in Continental Europe observed in the period from 2011-15 existed in the period 2006-08, then the aggregate output would have been 79 basis points lower. Thus, the output fall is larger than that estimated in Section 5.1.

\section{Alternative Measure of Shocks}

In an alternative approach to calibration, in place of estimating TFP parameter for each country as a residual in the production function, we download productivity data from the PWT $8.1 .^{30}$ Using this data, we calculate outputs which are somewhat different from the output provided in the data. We then estimate financial frictions and use estimated frictions to conduct the counterfactual experiments. Table E.12 in the Appendix shows that results remain similar: if financial frictions post-crisis existed in the pre-crisis period, we find that the output of the continental European economy would be 0.47 basis points lower. Further, Panel B shows that if financial frictions could be eliminated in the pre-crisis period, the GDP of continental European countries would have been 41 basis points higher.

Overall, our results show that additional gains for the European economy can be obtained over and beyond restoration of financial integration to the levels before the crisis. Our work does not take into account the costs of financial integration which include systemic risk experienced during the financial crisis. We just want to underscore the benefits of financial integration in this work, so that policymakers can make the appropriate trade-off.

\section{Conclusion}

The European experiment of political and economic integration is unparalleled. The financial crisis, the resulting worldwide tremors, the sovereign debt crises across Europe and various geopolitical problems including the recent British vote for exiting the union have created significant challenges for the European policymakers.

\footnotetext{
${ }^{30}$ Data for the U.S., total factor productivity at constant national prices, is available as "rtfp", which normalizes $A_{U S}=1$ for 2005. Data for other countries is available as "ctfp" relative to the U.S. that year. We obtain the values for $A_{i}$ for each country as the product of these two series.
} 
This paper seeks to highlight the benefits of financial integration that Europe enjoyed before the crisis and the costs of financial disintegration since then. Our analysis shows that financial disintegration leads to $0.54 \mathrm{pp}$ drop in GDP since the crisis. In contrast, if financial frictions are reduced, even beyond what existed before the financial crisis, we find that European GDP could increase by an additional $0.37 \mathrm{pp}$. Thus, we argue that while financial separation is useful to limit contagion during a crisis, such ringfencing comes at certain costs borne by firms and consumers at other times.

Two important limitations of our work are worth mentioning. First, we employ a static model which does not take into account the relative dynamics of the European economies beyond the productivity inter-relationships that we consider. While a static model may be sufficient for our purposes in this work, it may not be sufficient for future work which may consider, say, longterm equilibrium implications of variation in financial frictions across countries. We also do not consider systemic risk in this model, because other researchers have investigated it very carefully.

The policymakers face a trade-off. Our work seeks to assist them and the European Union in general on their path to a more prosperous union.

\section{References}

Alessandria, G., Choi, H., Kaboski, J. P., Midrigan, V., 2015. Microeconomic uncertainty, international trade, and aggregate fluctuations. Journal of Monetary Economics 69, 20 - 38.

Alessandria, G., Kaboski, J., Midrigan, V., 2013. Trade wedges, inventories, and international business cycles. Journal of Monetary Economics 60 (1), 1 - 20.

Alessandria, G., Kaboski, J. P., Midrigan, V., December 2010a. Inventories, lumpy trade, and large devaluations. American Economic Review 100 (5), 2304-39.

Alessandria, G., Kaboski, P. J., Midrigan, V., 2010b. The great trade collapse of 2008-09: An inventory adjustment? IMF Economic Review 58 (2), 254-294.

Aviat, A., Coeurdacier, N., 2007. The geography of trade in goods and asset holdings. Journal of International Economics 71 (1), 22 - 51.

Backus, D. K., Kehoe, P. J., Kydland, F. E., 1992. International real business cycles. Journal of Political Economy 100 (4), 745-775.

Barth, J. R., Gerard Caprio, J., Levine, R., January 2013. Bank regulation and supervision in 180 countries from 1999 to 2011 . Working Paper 18733, National Bureau of Economic Research. 
Beck, T., Levine, R., Loayza, N., 2000. Finance and the sources of growth. Journal of Financial Economics 58 (12), 261 - 300, Special Issue on International Corporate Governance.

Bolton, P., Jeanne, O., Jun 2011. Sovereign default risk and bank fragility. IMF Economic Review 59 (2), 162-194.

Caliendo, L., Parro, F., 2015. Estimates of the trade and welfare effects of NAFTA. The Review of Economic Studies 82 (1), 1-44.

Calvo, G. A., November 1998. Capital Flows and Capital-Market Crises: The Simple Economics of Sudden Stops. Journal of Applied Economics 0, 35-54.

Cetorelli, N., Goldberg, L. S., 2012a. Banking globalization and monetary transmission. The Journal of Finance 67 (5), 1811-1843.

Cetorelli, N., Goldberg, L. S., 2012b. Follow the money: Quantifying domestic effects of foreign bank shocks in the great recession. American Economic Review 102 (3), 213-18.

Cetorelli, N., Strahan, P. E., 2006. Finance as a barrier to entry: Bank competition and industry structure in local u.s. markets. The Journal of Finance 61 (1), 437-461.

Chang, R., Velasco, A., 2001. A model of financial crises in emerging markets. The Quarterly Journal of Economics 116 (2), 489-517.

Christoffersen, P., Errunza, V., Jacobs, K., Langlois, H., 2012. Is the potential for international diversification disappearing? a dynamic copula approach. Review of Financial Studies 25 (12), 3711-3751.

Cole, H. L., Obstfeld, M., August 1991. Commodity trade and international risk sharing : How much do financial markets matter? Journal of Monetary Economics 28 (1), 3-24.

Conesa, J. C., Kitao, S., Krueger, D., March 2009. Taxing capital? Not a bad idea after all! American Economic Review 99 (1), 25-48.

Diamond, D. W., 1984. Financial intermediation and delegated monitoring. The Review of Economic Studies 51 (3), 393-414.

Eaton, J., Mar. 1994. Cross-Border Banking. NBER Working Papers 4686, National Bureau of Economic Research, Inc.

European Commission, April 2015. European financial stability and integration review. European Commission Staff Working Document, 1 - 224.

Farhi, E., Tirole, J., Jan. 2014. Deadly Embrace: Sovereign and Financial Balance Sheets Doom Loops. Working Paper 164191, Harvard University OpenScholar.

Fernández, A., Klein, M. W., Rebucci, A., Schindler, M., Uribe, M., February 2015. Capital control measures: A new dataset. Working Paper 20970, National Bureau of Economic Research.

Fillat, J., Garetto, S., Goetz, M., 2016. Multinational Banks. Working paper, Boston University. 
Fillat, J. L., Garetto, S., Oldenski, L., 2015. Diversification, cost structure, and the risk premium of multinational corporations. Journal of International Economics 96 (1), 37-54.

Forbes, K., Reinhardt, D., Wieladek, T., Jan. 2016. The spillovers, interactions, and (un)intended consequences of monetary and regulatory policies. Discussion Papers 44, Monetary Policy Committee Unit, Bank of England.

Gertler, M., Kiyotaki, N., 2010. Chapter 11 - Financial intermediation and credit policy in business cycle analysis. In: Friedman, B. M., Woodford, M. (Eds.), Handbook of Monetary Economics. Vol. 3 of Handbook of Monetary Economics. Elsevier, Amsterdam, Netherlands, pp. 547 - 599.

Gertler, M., Kiyotaki, N., Queralto, A., 2012. Financial crises, bank risk exposure and government financial policy. Journal of Monetary Economics 59 (S), S17-S34.

Goldberg, L. S., April 2009. Understanding Banking Sector Globalization. IMF Staff Papers 56 (1), 171-197.

Goldberg, L. S., 2016. The cross-border banking landscape: Cross-border banking flows and organizational complexity in financial conglomerates. In: Demirguc-Kunt, A., Evanoff, D. D., Kaufman, G. G. (Eds.), The Future of Large, Internationally Active Banks. World Scientific Publishing.

Gopalan, R., Udell, G. F., Yerramilli, V., 11 2011. Why do firms form new banking relationships? Journal of Financial and Quantitative Analysis 46, 1335-1365.

Guvenen, F., 2011. Macroeconomics with hetereogeneity: A practical guide. Economic Quarterly (3Q), 255-326.

Holmstrom, B., 1982. Moral hazard in teams. The Bell Journal of Economics 13 (2), 324-340.

Houston, J. F., Lin, C., Ma, Y., 2012. Regulatory arbitrage and international bank flows. The Journal of Finance 67 (5), 1845-1895.

Jayaratne, J., Strahan, P. E., 1996. The finance-growth nexus: Evidence from bank branch deregulation 111 (3), 639-670.

Jermann, U., Quadrini, V., 2012. Macroeconomic effects of financial shocks. American Economic Review 102 (1), 238-71.

Judd, K. L., 1998. Numerical Methods in Economics. MIT Press, Cambridge, MA.

Kerr, W. R., Nanda, R., 2009. Democratizing entry: Banking deregulations, financing constraints, and entrepreneurship. Journal of Financial Economics 94 (1), 124 - 149.

King, R. b., Levine, R., 1993a. Finance, entrepreneurship and growth. Journal of Monetary Economics 32 (3), 513-542, cited By 775.

King, R. G., Levine, R., 1993b. Finance and growth: Schumpeter might be right. The Quarterly Journal of Economics 108 (3), 717-737. 
Lane, P. R., Milesi-Ferretti, G. M., 2007. The external wealth of nations mark II: Revised and extended estimates of foreign assets and liabilities, 1970 - 2004. Journal of International Economics 73 (2), $223-250$.

Lewis, K. K., November 2006. Is the international diversification potential diminishing? Foreign equity inside and outside the U.S. Working Paper 12697, National Bureau of Economic Research.

Maliar, L., Maliar, S., 2014. Chapter 7 - Numerical methods for large-scale dynamic economic models. In: Schmedders, K., Judd, K. L. (Eds.), Handbook of Computational Economics Vol. 3. Vol. 3 of Handbook of Computational Economics. Elsevier, pp. 325 - 477.

Niepmann, F., April 2013. Banking across borders. Federal Reserve Bank Staff Report 609.

Niepmann, F., 2015. Banking across borders. Journal of International Economics 96 (2), 244 265.

Peek, J., Rosengren, E. S., March 2000. Collateral damage: Effects of the japanese bank crisis on real activity in the united states. American Economic Review 90 (1), 30-45.

Quinn, D. P., Voth, H.-J., 2008. A century of global equity market correlations. The American Economic Review 98 (2), 535-540.

Redding, S. J., Sturm, D. M., 2008. The costs of remoteness: Evidence from german division and reunification. American Economic Review 98 (5), 1766-97.

Rice, T., Strahan, P. E., 2010. Does credit competition affect small-firm finance? The Journal of Finance 65 (3), 861-889.

Slovik, P., Cournéde, B., 2011. Macroeconomic impact of Basel III. OECD Publishing, Paris.OECD Economics Department Working Papers No. 844.

Stein, J. C., 2009. Presidential address: Sophisticated investors and market efficiency. The Journal of Finance 64 (4), 1517-1548.

Stockman, A. C., Tesar, L. L., March 1995. Tastes and Technology in a Two-Country Model of the Business Cycle: Explaining International Comovements. American Economic Review 85 (1), 168-85.

Uhlig, H., 2014. Sovereign default risk and banks in a monetary union. German Economic Review $15(1), 23-41$.

Zangwill, W. I., Garcia, C. B., 1981. Equilibrium programming: The path following approach and dynamics. Mathematical Programming 21 (1), 262-289. 

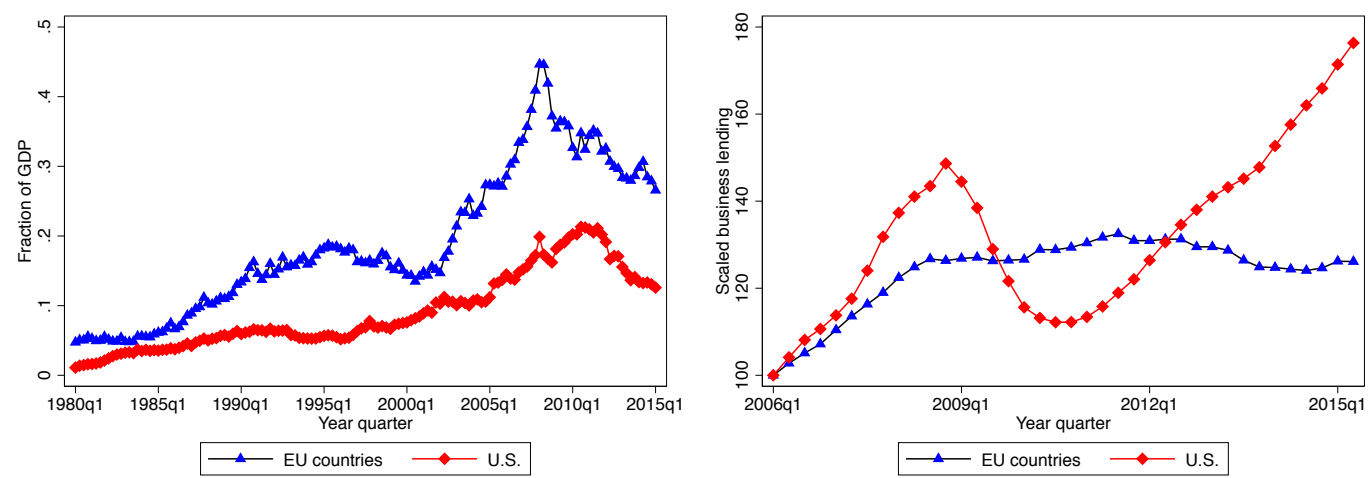

(a) Cross-border Financing and Commercial \& Industrial Lending around the Crisis
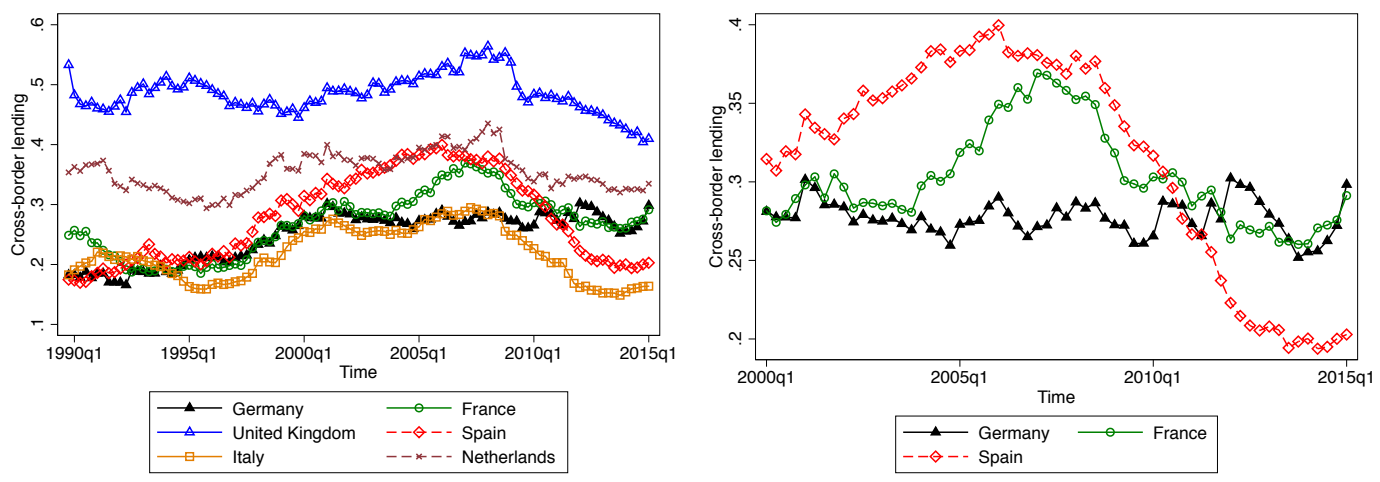

(b) Cross-border Financing over time

Figure 1: Cross-border Financing in Europe around the Crisis

Note: The left figure of Panel (a) reports the cross-border claims outstanding as a fraction of GDP against the respective economies. Data are obtained from BIS Statistics Explorer Table C3 (See http://stats.bis.org/statx/srs/table/c3, details in Section 2). GDP data are obtained from PWT 8.1. The right figure of Panel (a) reports business loans in EU countries and in the U.S. normalized to 100 in the year 2006. Data are obtained from ECB Statistical Data Warehouse (See https://sdw.ecb.europa.eu/browse.do?node=8549726) and the Federal Reserve Bank of St. Louis (FRED Economic Data, See https://fred.stlouisfed.org/series/BUSLOANS/). Panel (b) of the figure reports the incoming cross-border claims outstanding against each country as a fraction of total claims outstanding by all financial institutions who have claims outstanding (domestic and foreign) against the respective country in the respective years. Data from BIS is used to calculate cross-border financing (BIS Statistics Explorer Table C3, details in Section 2). 

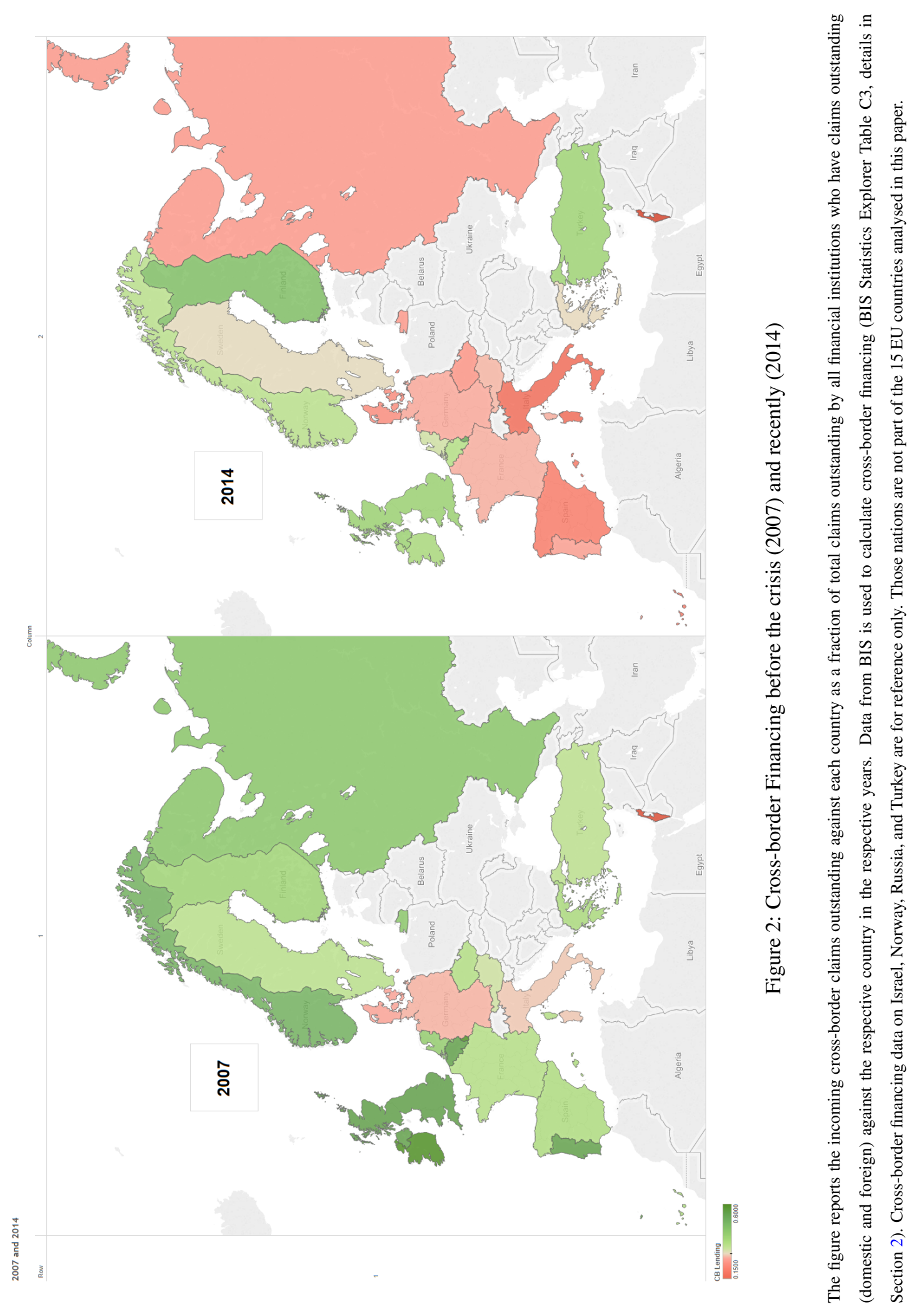

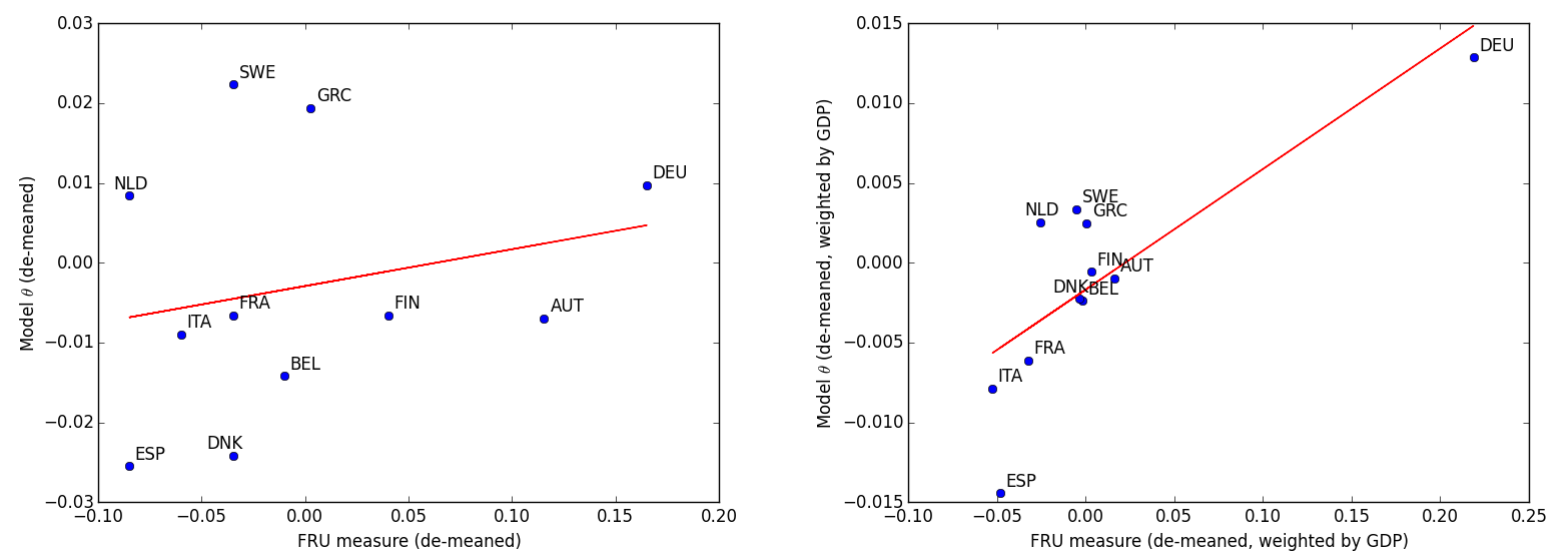

Figure 3: Financial Friction in European Economies

Note: The figure tests the external validity of the estimated financial frictions, with respect to an index of overall restrictions created by Fernández et al. (2015) (FRU). Using the Annual Report on Exchange Arrangements and Exchange Restrictions by IMF, Fernández et al. (2015) creates a dataset of capital control restrictions on both inflow and outflows of 10 categories of assets for 100 countries over the period of 1995-2013. We find that, for the post-crisis sample period of 2008-2011 in continental Europe, the cross-sectional correlation between the overall restrictions index and our estimated financial frictions is 22.9 percent (left panel). The two vectors are demeaned before calculating correlation to avoid spurious correlation. Luxembourg is not in the dataset of Fernández et al. (2015), and hence is excluded in the reported correlation. We also exclude Portugal which has a very high capital control index number compared to Spain, even though our estimates suggest Spain and Portugal are similar in terms of capital control. The right panel shows that GDP weighted cross-sectional correlation estimate is 78.7 percentage points. 


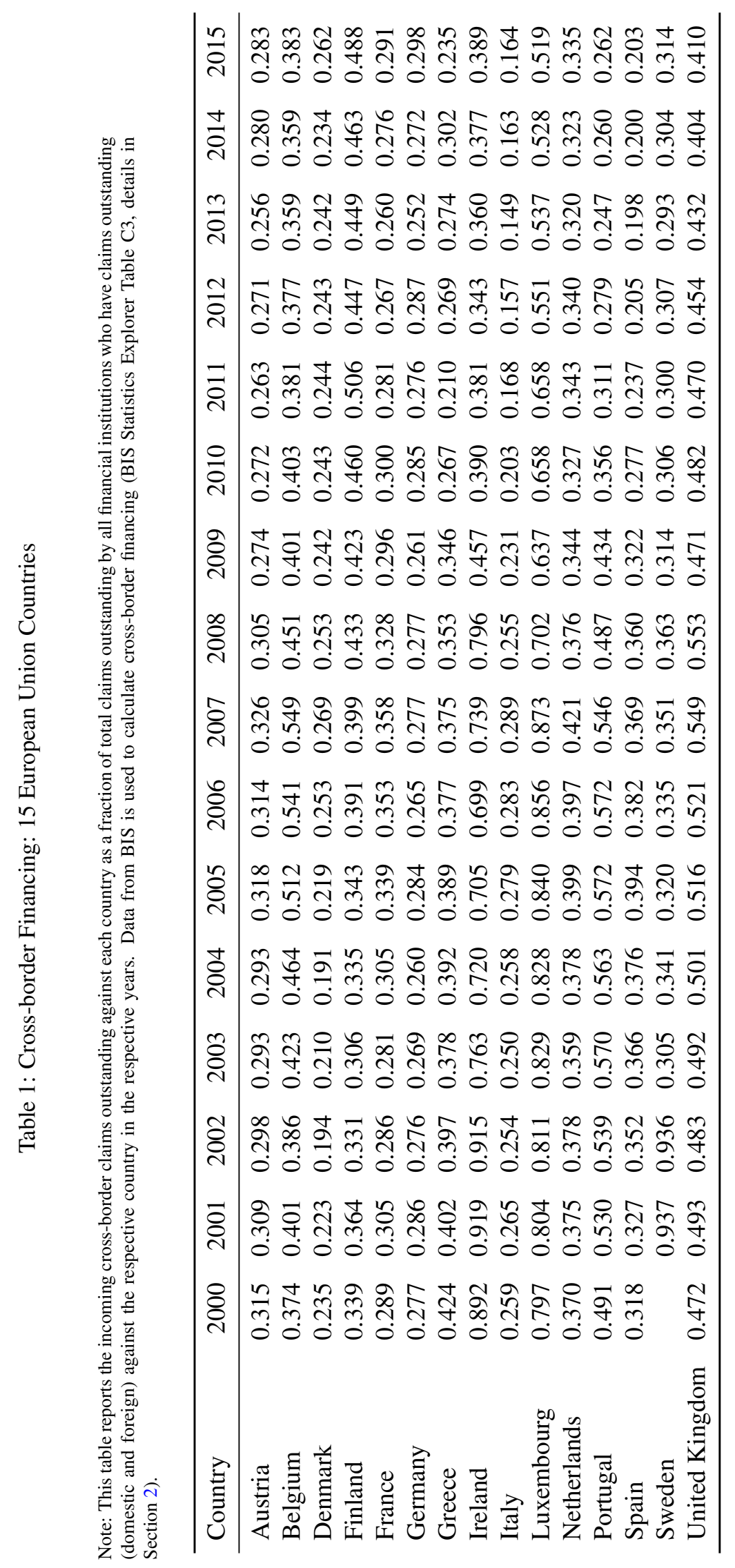


Table 2: Summary Statistics of 15 EU Countries

Note: The set of countries are those that joined the European Union by 1 January 1995. The next set of countries joined on 1st May 2004. Our sample selection ensures that we have long enough time series observations prior to 2007 for each country and thus can calculate the variance and covariance matrix of their joint productivity. Data period is from 2000 to 2011. One year after the introduction of Euro in 1999, we consider the year 2000 to be a good starting point. This is because 2011 is the latest year for which data is available from Penn World Tables (PWT) 8.1 (Lane and Milesi-Ferretti, 2007). (i) Capital depreciation rate $\delta$ is the "delta" series from PWT 8.1. (ii) Labor supply $L$ is the product of the number of persons employed ("emp" series) and the average annual hours worked by the employed person ("avh" series in PWT). (iii) The share of labor compensation $\alpha$ in GDP is obtained from "labsh" series in PWT, (iv) the value of capital stock $K$ is obtained from "ck" series, and (v) output in each country, $Y$ is the "cgdpo" series. (vi) Investment level $I$ for each country per year is obtained from "csh" and "cgdpo" series. (vii) The value of initial capital in country $i$ is calculated as $K_{i 0}=\left(K_{i}-I_{i}\right) /\left(1-\delta_{i}\right)$. (viii) We estimate TFP parameter for each country and each period as the residual in the production function, $A_{i}=Y_{i} /\left(K_{i}^{\alpha_{i}} L_{i}^{1-\alpha_{i}}\right) . Y_{i}$ and $L_{i}$ in 2005 in Great Britain in our sample is set to 1. (ix) Savings, $S$, is the sum of current account and investment. The table reports significant differences in the reported characteristics. The relative prosperity and productivity, with respect to the U.S., also varies significantly.

Panel A: Years 2000-2007

\begin{tabular}{lrrrrrrrrr}
\hline & $\delta$ & $\mathrm{L}$ & $\mathrm{TFP}$ & $\alpha$ & $\mathrm{K}$ & $\mathrm{Y}$ & $\mathrm{S}$ & $K_{0}$ & $\mathrm{I}$ \\
\hline AUT & 0.0430 & 0.1410 & 0.6273 & 0.3794 & 0.4654 & 0.1391 & 0.0352 & 0.4501 & 0.0347 \\
BEL & 0.0428 & 0.1375 & 0.7410 & 0.3757 & 0.5183 & 0.1671 & 0.0435 & 0.4972 & 0.0423 \\
DEU & 0.0377 & 1.1746 & 0.7140 & 0.3642 & 4.1276 & 1.3241 & 0.2701 & 4.0191 & 0.2599 \\
DNK & 0.0405 & 0.0903 & 0.6846 & 0.3512 & 0.2904 & 0.0930 & 0.0231 & 0.2792 & 0.0226 \\
ESP & 0.0339 & 0.6480 & 0.6059 & 0.3468 & 1.9358 & 0.5668 & 0.1640 & 1.8254 & 0.1718 \\
FIN & 0.0358 & 0.0854 & 0.5963 & 0.4092 & 0.2875 & 0.0835 & 0.0212 & 0.2775 & 0.0199 \\
FRA & 0.0351 & 0.8125 & 0.7241 & 0.3715 & 2.8709 & 0.9316 & 0.1963 & 2.7725 & 0.1954 \\
GBR & 0.0423 & 0.9913 & 0.7461 & 0.3649 & 2.0414 & 0.9600 & 0.1743 & 1.9436 & 0.1794 \\
GRC & 0.0368 & 0.2049 & 0.4531 & 0.4733 & 0.4067 & 0.1279 & 0.0317 & 0.3867 & 0.0342 \\
IRL & 0.0388 & 0.0734 & 0.8614 & 0.5130 & 0.1444 & 0.0877 & 0.0208 & 0.1281 & 0.0212 \\
ITA & 0.0414 & 0.9112 & 0.5335 & 0.4600 & 3.3247 & 0.8757 & 0.2259 & 3.2297 & 0.2285 \\
LUX & 0.0434 & 0.0097 & 0.7665 & 0.4222 & 0.0404 & 0.0135 & 0.0045 & 0.0379 & 0.0042 \\
NLD & 0.0383 & 0.2429 & 0.7821 & 0.3802 & 0.8181 & 0.3006 & 0.0618 & 0.7903 & 0.0580 \\
PRT & 0.0428 & 0.2064 & 0.4331 & 0.3181 & 0.3747 & 0.1077 & 0.0288 & 0.3588 & 0.0312 \\
SWE & 0.0484 & 0.1468 & 0.7797 & 0.3478 & 0.3276 & 0.1511 & 0.0326 & 0.3125 & 0.0301 \\
\hline \hline
\end{tabular}

Panel B: Years 2008-2011

\begin{tabular}{lrrrrrrrrr}
\hline & $\delta$ & $\mathrm{L}$ & $\mathrm{TFP}$ & $\alpha$ & $\mathrm{K}$ & $\mathrm{Y}$ & $\mathrm{S}$ & $K_{0}$ & $\mathrm{I}$ \\
\hline AUT & 0.0417 & 0.1452 & 0.5844 & 0.3931 & 0.6372 & 0.1517 & 0.0404 & 0.6238 & 0.0394 \\
BEL & 0.0435 & 0.1485 & 0.6401 & 0.3804 & 0.7667 & 0.1774 & 0.0534 & 0.7456 & 0.0536 \\
DEU & 0.0367 & 1.1927 & 0.6731 & 0.3910 & 5.3457 & 1.4433 & 0.2972 & 5.2598 & 0.2791 \\
DNK & 0.0414 & 0.0917 & 0.6837 & 0.3119 & 0.4149 & 0.1004 & 0.0259 & 0.4068 & 0.0249 \\
ESP & 0.0342 & 0.6665 & 0.5673 & 0.3494 & 3.5068 & 0.6752 & 0.1978 & 3.4182 & 0.2056 \\
FIN & 0.0344 & 0.0893 & 0.5615 & 0.3946 & 0.4118 & 0.0917 & 0.0229 & 0.4032 & 0.0225 \\
FRA & 0.0345 & 0.8271 & 0.6497 & 0.3756 & 4.3790 & 1.0048 & 0.2386 & 4.2849 & 0.2417 \\
GBR & 0.0403 & 0.9966 & 0.6622 & 0.3673 & 3.0760 & 0.9972 & 0.1843 & 3.0090 & 0.1883 \\
GRC & 0.0391 & 0.2073 & 0.4185 & 0.4825 & 0.5713 & 0.1415 & 0.0285 & 0.5614 & 0.0318 \\
IRL & 0.0404 & 0.0702 & 0.7075 & 0.4705 & 0.2854 & 0.0959 & 0.0176 & 0.2788 & 0.0179 \\
ITA & 0.0406 & 0.9189 & 0.4859 & 0.4486 & 4.5110 & 0.9112 & 0.2266 & 4.4602 & 0.2318 \\
LUX & 0.0424 & 0.0116 & 0.5846 & 0.4960 & 0.0609 & 0.0154 & 0.0053 & 0.0583 & 0.0050 \\
NLD & 0.0372 & 0.2515 & 0.7178 & 0.3878 & 1.2232 & 0.3332 & 0.0721 & 1.2004 & 0.0674 \\
PRT & 0.0403 & 0.1997 & 0.4113 & 0.3378 & 0.5730 & 0.1172 & 0.0289 & 0.5644 & 0.0313 \\
SWE & 0.0486 & 0.1583 & 0.7064 & 0.3642 & 0.4520 & 0.1639 & 0.0378 & 0.4381 & 0.0352 \\
\hline
\end{tabular}


Table 3: Calibration of Financial Integration Haircuts

Note: This table reports estimation of financial frictions obtained using post financial crisis data and the model in the paper. The estimation of friction is using moments on foreign share of financing. The aggregate investment moments are reported to show out of sample validity. Discounts are reported relative to the minimum discount estimated (Portugal), where numbers reported are $e^{-\theta}$.

\begin{tabular}{lrrrrr}
\hline & $\begin{array}{r}\text { Internal } \\
\text { Calib. Pars. }\end{array}$ & \multicolumn{2}{c}{$\begin{array}{c}\text { Panel A: Targeted Mom. } \\
\text { Foreign Inv. Share }\end{array}$} & \multicolumn{2}{c}{$\begin{array}{c}\text { Panel Untargeted Mom. } \\
\text { Agg. Inv. }\end{array}$} \\
\hline Discount & \multicolumn{1}{c}{ Model } & Data & Model & Data \\
\hline BEL & 0.9773 & 0.3049 & 0.3083 & 0.0387 & 0.0394 \\
DEU & 0.9843 & 0.4532 & 0.4563 & 0.0526 & 0.0536 \\
DNK & 0.9611 & 0.2670 & 0.2743 & 0.2116 & 0.2791 \\
ESP & 0.9942 & 0.2176 & 0.2243 & 0.0262 & 0.0249 \\
FIN & 0.9955 & 0.3524 & 0.3605 & 0.2287 & 0.2056 \\
FRA & 0.9769 & 0.3456 & 0.3510 & 0.0304 & 0.0225 \\
GBR & 0.9769 & 0.3016 & 0.3145 & 0.1775 & 0.2417 \\
GRC & 0.9537 & 0.4989 & 0.5034 & 0.2147 & 0.1883 \\
IRL & 0.9518 & 0.3803 & 0.3918 & 0.0322 & 0.0318 \\
ITA & 0.9272 & 0.7910 & 0.7940 & 0.0529 & 0.0179 \\
LUX & 0.9792 & 0.2589 & 0.2671 & 0.2429 & 0.2318 \\
NLD & 0.9621 & 0.8251 & 0.8298 & 0.0226 & 0.0050 \\
PRT & 0.9623 & 0.3836 & 0.3846 & 0.0687 & 0.0674 \\
SWE & 1.0000 & 0.5505 & 0.5479 & 0.0415 & 0.0313 \\
Imodel-data| & 0.9490 & 0.5013 & 0.5036 & 0.0357 & 0.0352 \\
\hline \multicolumn{7}{c}{0.00677} \\
\hline
\end{tabular}


Table 4: Financial frictions over time

Note: The table reports the estimated frictions before the financial crisis and those estimated post financial crisis. The next two columns also show the change in financial frictions post crisis with equal weights and with GDP weights respectively. The GDP weighted $e^{-\theta}$ for European countries pre-crisis is 0.9831 , and post-2007 is 0.9739 . The friction in this case is $1-e^{-\theta}$, which is the loss due to limited financial integration. Therefore, the haircut increases from $1.69 \%$ to $2.61 \%$ from before the financial crisis to after the crisis, a 54.3 percent increase in financial frictions post crisis.

\begin{tabular}{lrrrr}
\hline & Pre-2007 & Post-2007 & Change & $\begin{array}{r}\text { GDP wted. } \\
\text { change }\end{array}$ \\
\hline AUT & 0.9846 & 0.9773 & -0.0074 & -0.0010 \\
BEL & 0.9900 & 0.9843 & -0.0057 & -0.0010 \\
DEU & 1.0000 & 0.9611 & -0.0389 & -0.0515 \\
DNK & 0.9996 & 0.9942 & -0.0054 & -0.0005 \\
ESP & 0.9955 & 0.9955 & 0.0000 & 0.0000 \\
FIN & 0.9738 & 0.9769 & 0.0030 & 0.0003 \\
FRA & 0.9851 & 0.9769 & -0.0082 & -0.0077 \\
GRC & 0.9148 & 0.9518 & 0.0370 & 0.0047 \\
ITA & 0.9549 & 0.9792 & 0.0243 & 0.0213 \\
NLD & 0.9807 & 0.9623 & -0.0184 & -0.0055 \\
PRT & 0.9995 & 1.0000 & 0.0005 & 0.0001 \\
SWE & 0.9748 & 0.9490 & -0.0258 & -0.0039 \\
\hline Sum & & & & -0.0448 \\
GDP Loss & 0.0169 & 0.0261 & & -0.0092 \\
\hline
\end{tabular}


Table 5: Counterfactuals: European Economy without Financial (dis)integration

Note: This table reports the two counterfactuals conducted. The first counterfactual reports the output $(\mathrm{Y})$, wage $(\mathrm{W})$ and return on capital (R) for continental European economies (ex-Luxembourg) if they faced the same financial frictions before the financial crisis. The financial frictions have been estimated using the model and data from the post financial crisis period. The second counterfactual reports the same economic characteristics in case the European economy faced no financial frictions.

\begin{tabular}{lcccccc}
\hline & \multicolumn{3}{c}{ Panel A: Post-crisis frictions } & \multicolumn{3}{c}{ Panel B: No fin. frictions } \\
\hline & $\mathrm{Y}$ & $\mathrm{W}$ & $\mathrm{R}$ & $\mathrm{Y}$ & $\mathrm{W}$ & $\mathrm{R}$ \\
\hline AUT & 0.9928 & 0.9928 & 0.9930 & 0.9986 & 0.9992 & 0.9991 \\
BEL & 0.9844 & 0.9842 & 0.9844 & 1.0024 & 1.0025 & 1.0025 \\
DEU & 0.9898 & 0.9897 & 0.9898 & 1.0003 & 1.0003 & 1.0000 \\
DNK & 0.9968 & 0.9963 & 0.9965 & 1.0011 & 1.0006 & 1.0000 \\
ESP & 1.0018 & 1.0018 & 1.0010 & 1.0090 & 1.0091 & 1.0088 \\
FIN & 0.9976 & 0.9976 & 0.9983 & 1.0024 & 1.0017 & 1.0025 \\
FRA & 0.9975 & 0.9975 & 0.9975 & 1.0077 & 1.0076 & 1.0074 \\
GRC & 0.9937 & 0.9942 & 0.9940 & 0.9984 & 0.9991 & 0.9987 \\
ITA & 1.0001 & 1.0000 & 1.0000 & 1.0043 & 1.0044 & 1.0049 \\
NLD & 0.9900 & 0.9901 & 0.9900 & 1.0027 & 1.0026 & 1.0021 \\
PRT & 0.9889 & 0.9896 & 0.9892 & 1.0000 & 1.0000 & 1.0000 \\
SWE & 0.9841 & 0.9839 & 0.9844 & 1.0020 & 1.0015 & 1.0019 \\
\hline Total & 0.9946 & 0.9928 & 0.9929 & 1.0037 & 1.0026 & 1.0022 \\
\hline
\end{tabular}


Table 6: Welfare effects of financial frictions

Note: This table estimates the welfare losses from the financial (dis)integration of European economies post crisis, and also the possible welfare gains in counterfactual economy with no financial frictions. Columns (1) and (3) report the ratio of un-weighted and GDP weighted consumption (in percentage) lost due to financial frictions that were imposed in the post-crisis period. Columns (2) and (4) report consumption equivalent gains compared to the pre-crisis benchmark consumption in case that financial frictions could be completely eliminated.

\begin{tabular}{|c|c|c|c|c|}
\hline & \multicolumn{2}{|c|}{ Un-weighted } & \multicolumn{2}{|c|}{ GDP-Weighted } \\
\hline & $\begin{array}{l}\text { Post-crisis } \\
\text { frictions } \\
\text { (1) }\end{array}$ & $\begin{array}{l}\text { No fin. } \\
\text { frictions } \\
\text { (2) }\end{array}$ & $\begin{array}{l}\text { Post-crisis } \\
\text { frictions } \\
\text { (3) }\end{array}$ & $\begin{array}{l}\text { No fin. } \\
\text { frictions } \\
\text { (4) }\end{array}$ \\
\hline AUT & $-0.2280 \%$ & $0.4958 \%$ & $-0.0065 \%$ & $0.0141 \%$ \\
\hline BEL & $-0.1833 \%$ & $1.0347 \%$ & $-0.0063 \%$ & $0.0354 \%$ \\
\hline DEU & $-1.0359 \%$ & $0.0783 \%$ & $-0.2810 \%$ & $0.0212 \%$ \\
\hline DNK & $-0.1597 \%$ & $0.0682 \%$ & $-0.0030 \%$ & $0.0013 \%$ \\
\hline ESP & $0.0000 \%$ & $0.1226 \%$ & $0.0000 \%$ & $0.0142 \%$ \\
\hline FIN & $0.1004 \%$ & $0.9505 \%$ & $0.0017 \%$ & $0.0163 \%$ \\
\hline FRA & $-0.2240 \%$ & $0.9031 \%$ & $-0.0427 \%$ & $0.1723 \%$ \\
\hline GRC & $1.3260 \%$ & $3.3288 \%$ & $0.0347 \%$ & $0.0872 \%$ \\
\hline ITA & $0.8480 \%$ & $1.8650 \%$ & $0.1521 \%$ & $0.3345 \%$ \\
\hline NLD & $-0.5083 \%$ & $0.9766 \%$ & $-0.0313 \%$ & $0.0601 \%$ \\
\hline PRT & $0.0152 \%$ & $-0.3702 \%$ & $0.0003 \%$ & $-0.0082 \%$ \\
\hline SWE & $-0.7149 \%$ & $1.8219 \%$ & $-0.0221 \%$ & $0.0564 \%$ \\
\hline Average & $-0.0637 \%$ & $0.9396 \%$ & & \\
\hline Total & & & $-0.2041 \%$ & $0.8050 \%$ \\
\hline
\end{tabular}


Table 7: Financial frictions and output growth for 2006-08 and 2011-15.

\begin{tabular}{|c|c|c|c|c|c|}
\hline & 2006-08 & $2011-15$ & Change & $\begin{array}{l}\text { GDP weighted } \\
\text { change }\end{array}$ & $\begin{array}{c}\text { Counterfactual } \\
\text { Output }\end{array}$ \\
\hline AUT & 0.9801 & 0.9753 & -0.0048 & -0.0007 & 0.9914 \\
\hline BEL & 0.9812 & 0.9846 & 0.0034 & 0.0006 & 0.9903 \\
\hline DEU & 0.9675 & 0.9560 & -0.0115 & -0.0167 & 0.9894 \\
\hline DNK & 0.9893 & 0.9945 & 0.0053 & 0.0005 & 1.0220 \\
\hline ESP & 1.0000 & 0.9940 & -0.0060 & -0.0040 & 0.9928 \\
\hline FIN & 0.9777 & 0.9748 & -0.0028 & -0.0003 & 1.0000 \\
\hline FRA & 0.9823 & 0.9758 & -0.0065 & -0.0064 & 0.9882 \\
\hline GRC & 0.9579 & 0.9497 & -0.0082 & -0.0012 & 0.9900 \\
\hline ITA & 0.9875 & 0.9734 & -0.0141 & -0.0130 & 0.9940 \\
\hline NLD & 0.9597 & 0.9637 & 0.0039 & 0.0013 & 1.0027 \\
\hline PRT & 0.9995 & 1.0000 & 0.0005 & 0.0001 & 0.9879 \\
\hline SWE & 0.9478 & 0.9455 & -0.0023 & -0.0004 & 0.9871 \\
\hline $\begin{array}{l}\text { Sum } \\
\text { GDP Loss }\end{array}$ & 0.0242 & 0.0318 & & -0.0402 & 0.9921 \\
\hline
\end{tabular}




\section{The Real Effects of Financial (Dis)integration:}

\section{A Multi-Country Equilibrium Analysis of Europe}

\section{(Internet Appendix)}

\section{Appendix A. Data}

\section{Appendix A.1. Cross-border Capital Flow Data}

We utilize data from the Bank for International Settlements (BIS) to investigate how cross-border financing has changed in Europe. Table C3 from BIS Statistics Explorer provides detailed information about issuance and amounts outstanding by residence and nationality of issuer for 137 countries. ${ }^{31}$ The dataset breaks down claims outstanding by domestic and international claims against domestic firms, i.e. cross-border financing for each country. We obtain series $[2,1]$ and series $[16,1]$ for amounts of total and cross-border claims outstanding respectively for each country for each year in our sample period. ${ }^{32}$ Cross-border transactions occur either directly between a foreign capital provider and a firm, or between a foreign capital provider's subsidiary inside the country and the firm. In the latter case, an accounting identity on the books of the domestic subsidiary of the foreign capital provider ensures that for every domestic asset on the books of the subsidiary (which are claims against domestic firms), there is a cross-border liability (to the parent capital provider) outstanding in the books as well. Series $[16,1]$ of Table C3 thus provides the sum of these two types of international capital provision.

The series provide us the gross stock of claims outstanding against the domestic firms of a country period by period. Since, we use the data for calibrating a model of multi-country portfolio allocation, the stock of claims outstanding is appropriate in our opinion. Furthermore, since we allow cross-border claims to be present bilaterally for each country-pair in the model, gross claims

\footnotetext{
${ }^{31}$ See http://stats.bis.org/statx/srs/table/c3.

${ }^{32}$ See http://stats.bis.org/statx/srs/tseries/DEBT_SEC2/Q.DE.3P.1.1.1.A.A.T01.A.A.A.A.A. $I ? t=c 3 \& c=D E \& p=20134 \& i=2.1$ and http $: / /$ stats . bis .org $/$ statx $/$ srs $/$ t series/DEBT_SEC2/Q.DE . 3P.1.1 . C.A.A.T01 .A.A.A.A.A.I?t=c3\&c=DE\&p=20142\&i=16.1 respectively for the data on amounts outstanding per period per country, with an example case of Germany.
} 
outstanding as provided by the data are appropriate for calibration in our case. Both series are in billions of U.S. dollars. The dataset is rich in additional data including gross issuance, net flows, breakdown of amounts outstanding by banks compared to other financial and non financial corporations, and currency of claims outstanding.

\section{Appendix A.2. Country Level Data}

We use the PWT data for country level data. (i) Capital depreciation rate $\delta$ is obtained from "delta" series; (ii) Labor supply $L$ is the product of the number of persons employed ("emp" series) and the average annual hours worked by the employed person ("avh" series in PWT); (iii) To obtain the values for $\alpha_{i}$, we use the data on the share of labor compensation in GDP ("labsh" series in PWT). (iv) The value of capital stock $K$ is obtained from "ck" series, and (v) output in each country, $Y$ is the "cgdpo" series. (vi) Investment level I for each country per year is obtained from "cshi" and “cgdpo" $(Y)$ series.

We calculate the value of initial capital in country $i$ as $K_{i 0}=\left(K_{i}-I_{i}\right) /\left(1-\delta_{i}\right)$. In our model we assume that at the beginning of the period, each country has a certain amount of savings, $S_{i}$, which the economic agents in this country decide how to invest. We do not model the consumption versus savings decision in that time period but use current account and investment data to determine allocatable resources. This is because all capital stock may not be available for reallocation to other countries in a relatively short period of time. Thus, savings is not a measure of wealth but that of allocatable resources in our model. Finally, TFP parameter for each country and each period is the

residual in the production function, $A_{i}=Y_{i} /\left(K_{i}^{\alpha_{i}} L_{i}^{1-\alpha_{i}}\right)$. In an alternative approach, we take TFP as given and calculate the output for each country $Y_{i}$. We normalize $Y_{i}$ and $L_{i}$ in 2005 in the Great Britain in our sample to 1.

\section{Appendix A.3. Importance of Equity Flows compared to Debt Markets in Europe}

In our work, we consider the ratio of cross-border claims (which may include all types of securities such as debt, equity or more complicated contracts) obtained by domestic firms as a fraction of total financing obtained by firms, (i.e. within country liabilities and liabilities obtained from across the border) to calibrate financial frictions. In this section, we investigate the importance of equity 
financing in general and specifically if households take equity positions to offset exposure to countries taken through debt position. First, we believe that given that in Europe, financing is mostly done by banks, looking at debt to identify the ratio (not level) of domestic and foreign investment is acceptable. Second, we would like to stress that we only use the BIS Statistics Explorer data from Table $\mathrm{C} 3$ to measure the ratio rather than the level of foreign investment in a country. The BIS data is an established source for financial flow data (See Niepmann, 2015; Goldberg, 2016, among others).

Next, we need to show, that equity financing correlates with debt financing. Otherwise, equity financing may offset debt financing and the use of ratio of cross-border lending obtained only from debt financing data may not be a good assumption. We investigate the importance of European equity markets for our results, and to verify our assumption that equity and debt flows correlate. Table A.8 shows the summary statistics of the foreign debt and equity liabilities data of the European countries in our sample during the sample period 2000-2011. Using the updated data from Lane and Milesi-Ferretti (2007), we find that, for our sample period in our set of European countries, the correlation between foreign debt and equity liabilities as a fraction of domestic capital is very high at 0.9323 . The correlation between year over year changes in debt as a fraction of capital, and equity as a fraction of capital is 0.5753 . Thus, it is not the case that equity exposures are offsetting debt exposures to a country in the data. Furthermore, the average ratio of equity with respect to debt is approximately $26.45 \%$ in our sample. Thus, debt financing is the primary source of financing for the European countries. 
Table A.8: Debt and Equity Data from Penn World Tables

Note: Panel A reports the mean level of Debt/K, Equity/K and Equity/Debt in our sample of 15 European countries over the sample period (2000-2011). Panel B reports the correlation over time between debt and equity levels and changes respectively for the countries. 2011 is the latest year for which data is available from Penn World Tables (PWT) 8.1 and Lane and MilesiFerretti (2007). The table reports significant differences in the reported characteristics. The relative prosperity and productivity, with respect to the U.S., also varies significantly.

\begin{tabular}{lcrr}
\hline \multicolumn{4}{c}{ Panel A: Country level liabilities } \\
\hline & Debt/K & Equity/K & Equity/Debt \\
\hline AUT & 0.4747 & 0.1242 & 0.2591 \\
BEL & 0.6807 & 0.4058 & 0.6213 \\
DNK & 0.4062 & 0.1169 & 0.2894 \\
FIN & 0.2980 & 0.0794 & 0.2705 \\
FRA & 0.4011 & 0.1111 & 0.2776 \\
DEU & 0.3683 & 0.0806 & 0.2189 \\
GRC & 0.3583 & 0.0357 & 0.1040 \\
IRL & 3.0156 & 0.6045 & 0.2138 \\
ITA & 0.2356 & 0.0329 & 0.1407 \\
LUX & 8.6741 & 8.4490 & 1.0048 \\
NLD & 0.7720 & 0.2647 & 0.3431 \\
PRT & 0.4551 & 0.1010 & 0.2224 \\
ESP & 0.3003 & 0.0990 & 0.3278 \\
SWE & 0.5352 & 0.2367 & 0.4410 \\
GBR & 1.2657 & 0.1668 & 0.1323 \\
\hline Mean & 0.5357 & 0.1417 & 0.2645 \\
\hline \multicolumn{4}{c}{ Panel B: Additional Statistics } \\
\hline Debt-Equity Corr. & & 0.9323 \\
Debt-Equity Change Corr. & 0.5753 \\
\hline
\end{tabular}




\section{Appendix B. Europe as (an almost) Closed Economy}

As we discuss in Section 3, we consider general equilibrium in terms of capital allocation within the 15 European countries. A natural question is whether the assumption that Europe is a closed economy is too strong. Figure B.4 plots current account as a fraction of output of Germany and the remaining European countries in our dataset for the sample period 2000-2011. Data are obtained from Lane and Milesi-Ferretti (2007), which provides data on foreign assets and foreign liabilities for a large sample of countries for the period 1970-2011.

The left panel shows that current account as a fraction of GDP for our set of countries is on average approximately 0.5 percentage points. The second panel shows that there is a strong negative correlation between the current account of Germany and the remaining 14 countries, suggesting that capital is getting mostly allocated within the sample of countries. These observations provide confidence in our model's assumption where countries allocate capital only within the set of 15 European countries.
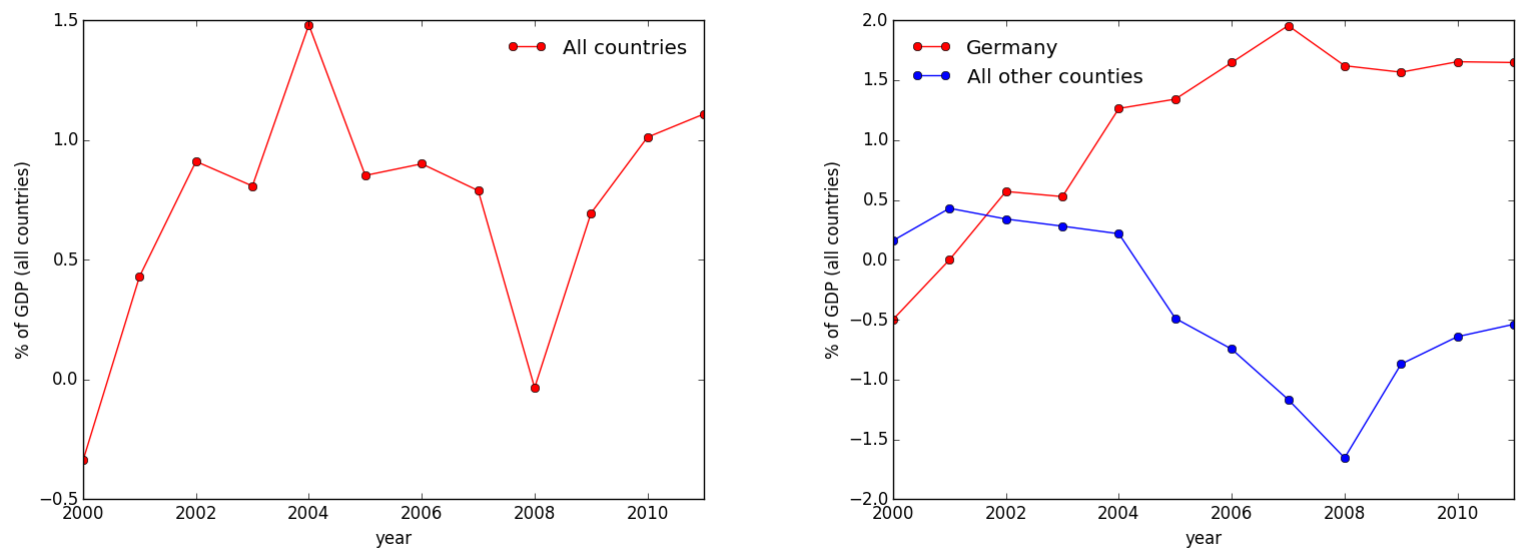

Figure B.4: Current Account of European Economies

Note: The figure plots current account as a fraction of output of Germany and the remaining European countries in our dataset for the sample period 2000-2011. Data are obtained from Lane and Milesi-Ferretti (2007). 


\section{Appendix C. Computational Algorithm}

We find the solution by solving the system of equilibrium conditions that include the firstorder optimality conditions for the financial institutions and market-clearing conditions which is described in Section 4.2. Because of the presence of the short-selling constraints, this system includes Kuhn-Tucker inequalities. We use the "Garcia-Zangwill trick" (See Zangwill and Garcia, 1981) to replace these inequalities with equations. This approach is essentially a change of variables, and works as follows. We fix a positive integer $k \geq 2$ (we use $k=2$ ), and define:

$$
\alpha^{+}=\left(\max \left[0, \alpha_{G Z}\right]\right)^{k}, \quad \alpha^{-}=\left(\max \left[0,-\alpha_{G Z}\right]\right)^{k} .
$$

Note that $\alpha^{+} \geq 0, \alpha^{-} \geq 0$ and $\alpha^{+} \alpha^{-}=0$.

Next, we reformulate the equilibrium system of equations as:

$$
\begin{aligned}
& s_{i} \mathbb{E} u^{\prime}\left(c_{i}\right)\left(R_{i j}-R_{i N}\right)+\alpha_{i j}^{+}-\alpha_{i N}^{+}=0, \quad \forall i, j, \\
& \alpha_{i j}^{-}-\phi_{i j}=0, \quad \forall i, j, \\
& c_{i}=w_{i}+\Phi_{i}^{\prime} R_{i} s_{i}, \quad \forall i, \\
& \phi_{i i}+\sum_{j \neq i} \phi_{i j}=1, \quad \forall i, \\
& \phi_{i i}^{*} s_{i} L_{i}+\sum_{j \neq i}^{N} \phi_{j i}^{*} s_{j} L_{j}+K_{i 0}\left(1-\delta_{i}\right)=K_{i}^{*}, \quad \forall i, \\
& w_{i}^{*}=\left(1-\alpha_{i}\right) A_{i}\left(K_{i}^{*}\right)^{\alpha_{i}} L_{i}^{-\alpha_{i}}, \quad \forall i, \\
& R_{i i}^{*}=1+\alpha_{i} A_{i}\left(K_{i}^{*}\right)^{\alpha_{i}-1} L_{i}^{1-\alpha_{i}}-\delta_{i}, \quad \forall i, \\
& R_{i j}^{*}=R_{j j}^{*} e^{-\theta_{j}}, \quad \forall i, j .
\end{aligned}
$$

The resulting system is equivalent to the one in Section 4.2 but does not contain inequalities. This allows us to use a non-linear solver to obtain a solution. ${ }^{33}$ We approximate the integrals that

\footnotetext{
${ }^{33}$ We use Knitro as a non-linear solver. The commercial software link is https://www.artelys.com/en/ optimization-tools/knitro.
} 
represent the expectations in the above equations using the monomial integration rules described in detail in Maliar and Maliar (2014). 


\section{Appendix D. Current Account and Investment}

Table D.9 reports the model generated current account and investment levels. It then compares the difference in current account values from data and model and the same for investment levels respectively. Data are from Penn World Tables (PWT) 8.1 and Lane and Milesi-Ferretti (2007). As expected, by construction, the differences for each country in terms of model and data match of current account and investment levels sum upto zero.

Table D.9: Difference between model and data generated Current Account and Investment

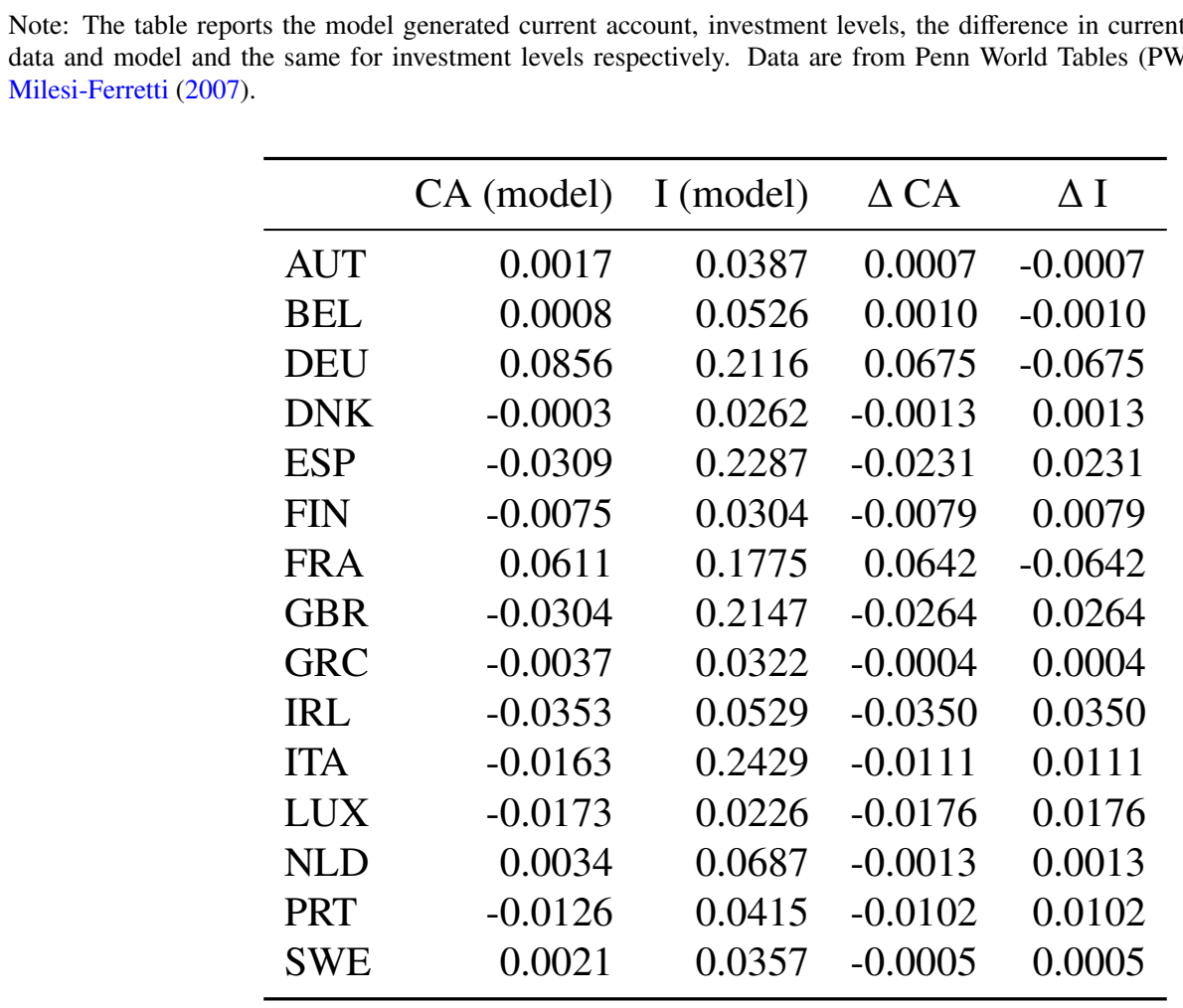

\section{Appendix E. Additional Tables and Figures}



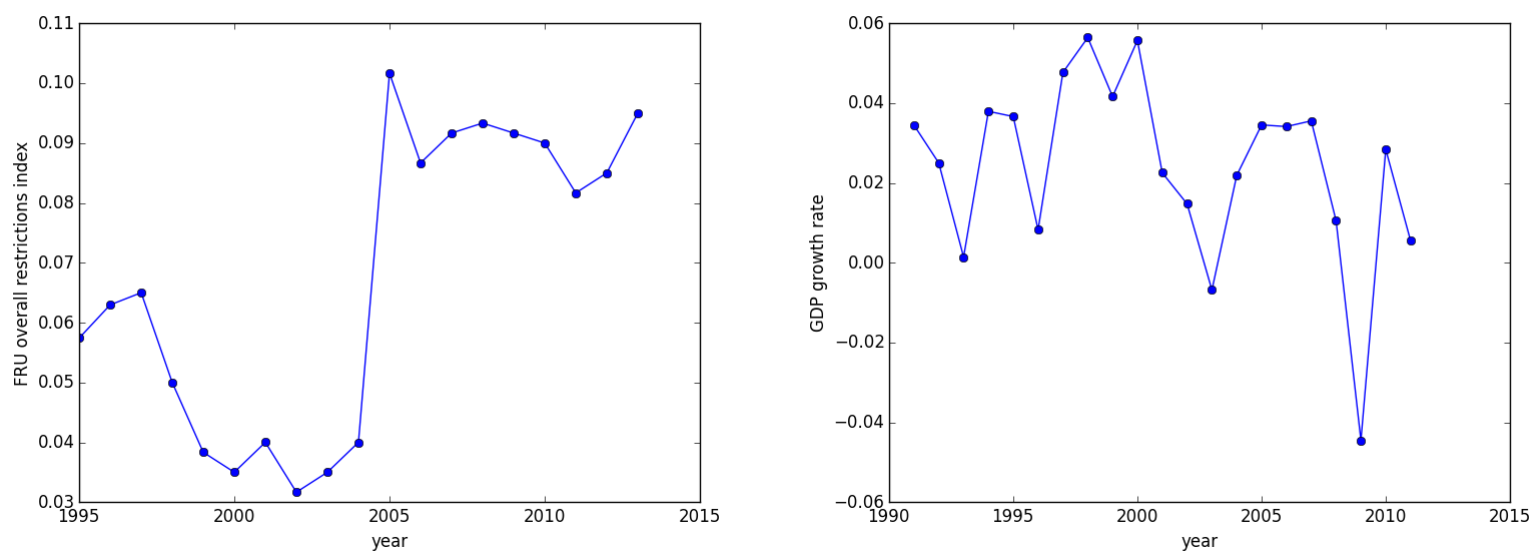

Figure E.5: Capital Control Restrictions and output growth rates in European Economies

Note: Using the Annual Report on Exchange Arrangements and Exchange Restrictions by IMF, Fernández et al. (2015) creates a dataset of capital control restrictions on both inflow and outflows of 10 categories of assets for 100 countries over the period of 1995-2013. The figure reports the overall restrictions index over the last 20 years in the 14 European Countries in our sample for which Fernández et al. (2015) (FRU) report their measure. Luxembourg is not in the dataset of Fernández et al. (2015). The second panel reports the output growth rates for the Continental EU countries for the two decade period of 1991-2011. 


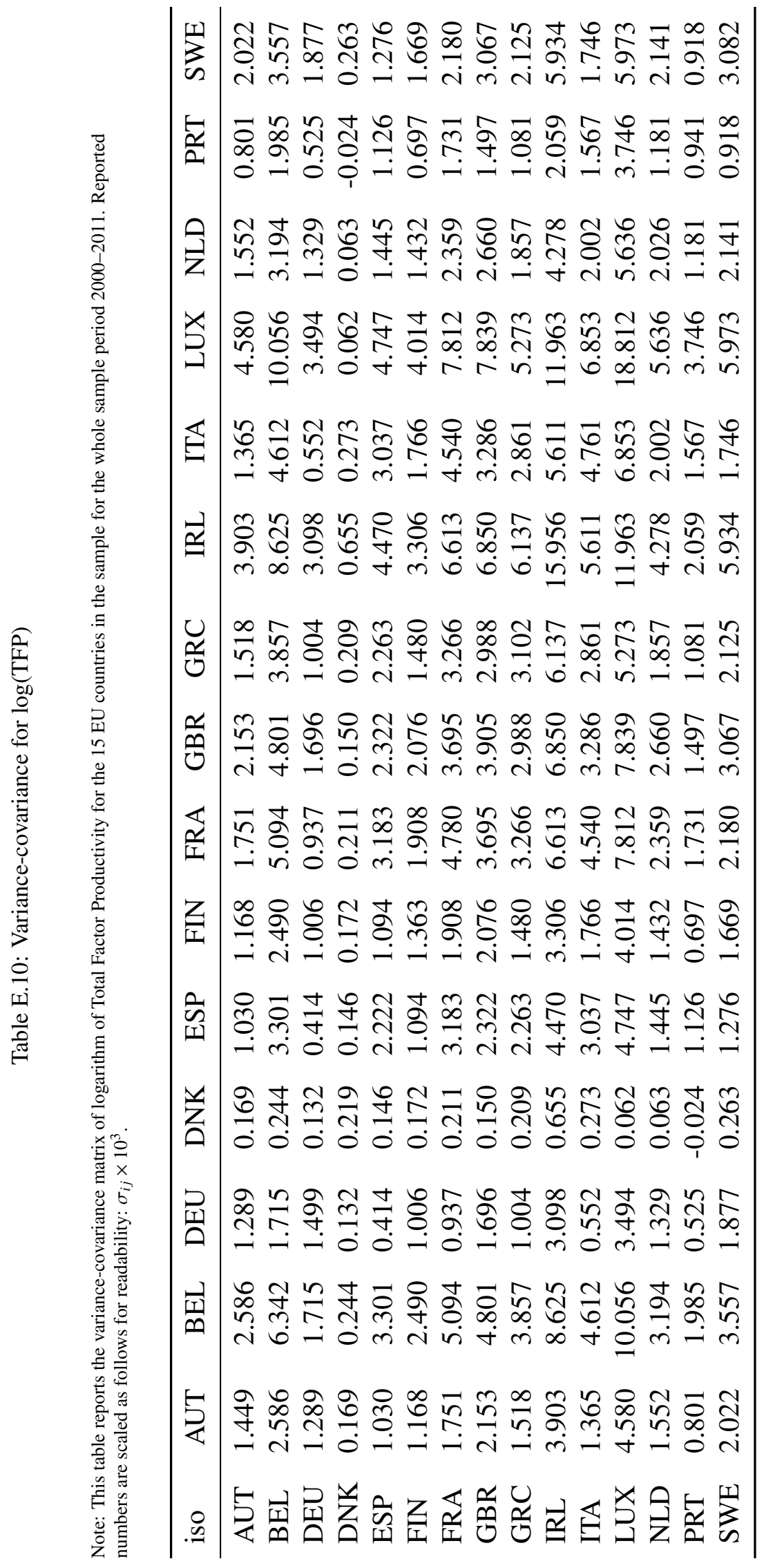


Table E.11: European Economy Average Output Growth Rates

Note: This table reports the average output growth rates in the Continental EU economies during the sample period using Penn World Tables 8.1 data.

\begin{tabular}{lrrr}
\hline & $2000-2007$ & $2008-2011$ & $1991-2011$ \\
\hline AUT & 0.0236 & 0.0069 & 0.0275 \\
BEL & 0.0231 & 0.0055 & 0.0236 \\
DEU & 0.0242 & 0.0026 & 0.0237 \\
DNK & 0.0223 & 0.0044 & 0.0236 \\
ESP & 0.0477 & -0.0025 & 0.0362 \\
FIN & 0.0310 & -0.0031 & 0.0224 \\
FRA & 0.0242 & 0.0041 & 0.0211 \\
GRC & 0.0350 & -0.0134 & 0.0272 \\
ITA & 0.0146 & -0.0087 & 0.0152 \\
NLD & 0.0378 & -0.0020 & 0.0313 \\
PRT & 0.0222 & -0.0014 & 0.0267 \\
SWE & 0.0278 & 0.0046 & 0.0244 \\
\hline GDP Weighted avg. & 0.0265 & 0.00001 & 0.0239 \\
\hline
\end{tabular}


Table E.12: Alternative Calibration and Counterfactuals: European Economy without Financial (dis)integration

Note: This table reports the two counterfactuals conducted using an alternative approach regarding calibration, where TFP data directly downloaded from Penn World Tables 8.1 is used rather than estimating it. The first counterfactual reports the output $(\mathrm{Y})$, wage $(\mathrm{W})$ and return on capital $(\mathrm{R})$ for continental European economies if they faced the same financial frictions before the financial crisis. The financial frictions have been estimated using the model and data from the post financial crisis period. The second counterfactual reports the same economic characteristics in case the European economy faced no financial frictions.

\begin{tabular}{lcccccc}
\hline & \multicolumn{3}{c}{ Panel A: Post-crisis frictions } & \multicolumn{3}{c}{ Panel B: No fin. frictions } \\
\hline & $\mathrm{Y}$ & $\mathrm{W}$ & $\mathrm{R}$ & $\mathrm{Y}$ & $\mathrm{W}$ & $\mathrm{R}$ \\
\hline AUT & 0.9934 & 0.9935 & 0.9933 & 1.0004 & 1.0006 & 1.0000 \\
BEL & 0.9863 & 0.9864 & 0.9864 & 1.0046 & 1.0047 & 1.0045 \\
DEU & 0.9937 & 0.9937 & 0.9937 & 1.0034 & 1.0034 & 1.0031 \\
DNK & 0.9981 & 0.9980 & 0.9980 & 1.0019 & 1.0021 & 1.0030 \\
ESP & 1.0006 & 1.0006 & 1.0010 & 1.0065 & 1.0065 & 1.0071 \\
FIN & 1.0018 & 1.0020 & 1.0016 & 1.0073 & 1.0072 & 1.0072 \\
FRA & 0.9990 & 0.9990 & 0.9991 & 1.0084 & 1.0084 & 1.0082 \\
GRC & 0.9805 & 0.9805 & 0.9806 & 0.9854 & 0.9853 & 0.9856 \\
ITA & 0.9965 & 0.9966 & 0.9967 & 1.0017 & 1.0017 & 1.0020 \\
NLD & 0.9943 & 0.9941 & 0.9940 & 1.0070 & 1.0070 & 1.0068 \\
PRT & 0.9846 & 0.9845 & 0.9847 & 0.9932 & 0.9931 & 0.9933 \\
SWE & 0.9895 & 0.9894 & 0.9895 & 1.0080 & 1.0079 & 1.0082 \\
\hline Total & 0.9953 & 0.9954 & 0.9954 & 1.0041 & 1.0040 & 1.0041 \\
\hline
\end{tabular}

